Ag':3:457

Bulletin 457

May, 1942

\title{
Tobacco Substation at Windsor Report for 1941
}

\author{
P. J. Anderson and T. R. Swanback
}

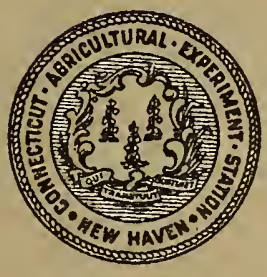

Connerticut

Agxicultuxal Fexpeximent Station

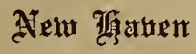




\section{Tobacco Substation at Windsor Report for 1941}

P. J. Anderson and 'T. R. Swanback

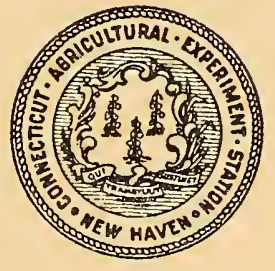

Connerticut

Agricultural Faperiment Station

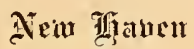




\section{CONTENTS}

PAGE

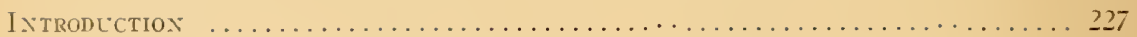

Tine Relative Crop-Frodecing Capacity of Lrea and Cottoxseed Meal. . . . 229

The Effect of Some Sotrces of Phospherus ox Cigar Leae Tobacco....... 234

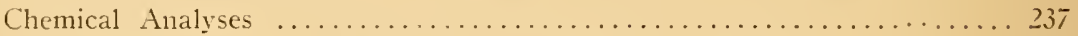

The Effect of Solrce on Magnesilia Absorption by Tobacco............ 239

Leaf Content of Magnesium and Calcium ................. $2+1$

Restdual Effect of Staple Maxure ...................... 242

Further Experinents on Starter Solltions .................... 243

Úse of Carbox Black to Activate Growth Farly in tie Seasox......... I 44

Ferther INFORMation on IRrigation of Tobacco................... +6

Lumarith as a Sébstitute for Glass in the Seed Bed Sash . . . . . . . . 2. 27

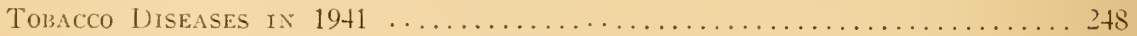

Some Experiments on the Control of Downy Nildew .............. 2 t8

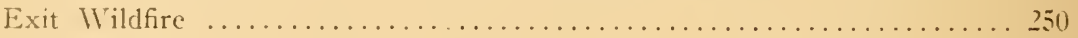

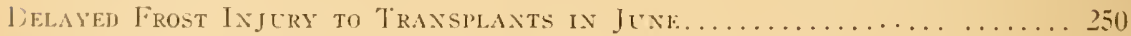

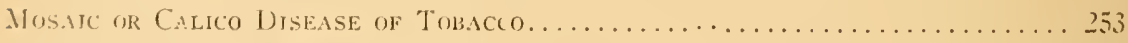

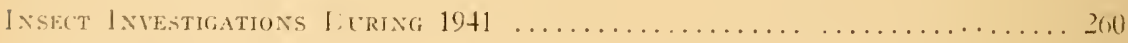

Flea bectle and Thrips Experiment ...................... 200

Cintrol Experiments on ()pen Field Tobacen .................... 201

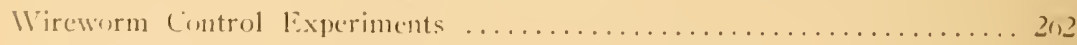

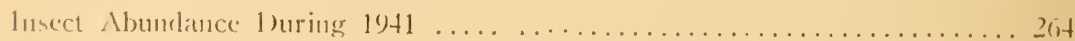




\title{
TOBACCO SUBSTATION AT WINDSOR
}

\section{Report for 1941}

\author{
P. J. Anderson and T. R. Swanpick
}

$\mathbf{T}$ HE Twentieth Annual Report of the Tobacco Substation at IVindsor is presented herewith. It is not the object of these annual reports to describe in detail all of the work done during the vear on each of many tobacco research projects. Most problems require a continuation through several years before a final answer can be given. In general, it seems best to wait until the conclusion of a project before discussing it in the annual report. On some, however, a progress report is considered necessary. A case in point is the study on phosphorus tests described in this bulletin. On account of world conditions, growers can no longer obtain certain phosphates they have been accustomed to use, and other kinds must be substituted. It may help the grower in choosing a substitute to present here the results of the first two years of a test on various phosphatic materials, even though we have not yet drawn final conclusions.

The growing season of 1941 was on the whole unusually favorable for the production of good tobacco in the Valley. A few local hail and wind storms caused considerable damage but these were confined to small areas. Rainfall was favorable in distribution and amount, as indicated in Table 1, and kept the crop growing steadily. There were no serious leaching rains. The curing season was quite dry, with the result that there was practically no pole rot in this year's crop. Most of the tobacco diseases were at a low ebb and there were no serious insect infestations.

Table 1. Distribution of Rainfall in Inches at the Tobacco Surstation, WINDSOR, 1941.

\begin{tabular}{ccc|ccc|ccc|ccc}
\hline \hline \multicolumn{1}{c}{ May } & \multicolumn{3}{c}{ June } & \multicolumn{3}{c}{ August } \\
\hline \multicolumn{10}{c}{ BY TEN-DAY PERIODS } \\
\hline $1-10$ & $11-20$ & $21-31$ & $1-10$ & $11-20$ & $21-30$ & $1-10$ & $11-20$ & $21-31$ \\
\hline 2.38 & .45 & .62 & 3.10 & 80 & .52 & 2.12 & .45 & 3.07 & .76 & 1.06 & .64 \\
\hline
\end{tabular}

BY MONTHS

3.45

4.42

5.64

2.46

AVERAGE FOR PRECEDING 19 YEARS 
Of the rarious forms of direct serrice offered by the Station, growers take most alvantage of the free soil testing service. Ther have learned to take their own samples. They bring these into the laboratory and. after tests have been made for acidity, nitrogen, potash. phosphorns. calcium, magnesimm and sometimes other elements. growers often sit down with the Station agronomist and figne out the best fertilizer formulas for their fields. on the basis of the soil tests. In $19+1$ over 4.000 samples of soil were bronght in and tested before the cromed became frozen and ended this work.

I sim of $\$ 1.500$ was appropriated for material to build a threecar brick garage. Plans were drawn. contracts let and materials delivered. but work was interrupted when the ground froze in December. This much needed addition to the plant will be finisher in the spring.

Table 2 shows the acreage and production of each of the three trpes of Connecticut Valley tobaceo for $19+1$ and a comparison with 1940 and an average of the previons ten rears. ${ }^{1}$ This table shows a small increase in acreage of Broadleaf, a smaller decrease in acreage of Havana Seed and a small increase in Shade. Both Shade and Harana Seed are well above the ten-year arerage. Only Havana seed shows a lare increase in poundage crer the ten-year arerage.

Table 2. Acreage and Prodection of Connecticut Valley Types in 1940 axd 1941 Compared with a Tex-year Average.

\begin{tabular}{|c|c|c|c|c|c|c|}
\hline \multirow[b]{2}{*}{ Types } & \multicolumn{3}{|c|}{ Acres } & \multicolumn{3}{|c|}{ Production in pounds } \\
\hline & 1941 & 1940 & $1930-39$ & 1941 & 1940 & $1930-39$ \\
\hline Broadleaf & 8,300 & 8,000 & 8,680 & $13,284,000$ & $12,326,000$ & $13,373,000$ \\
\hline Havana Seed & 8,100 & 8,200 & 7,690 & $14,166,000$ & $14,111,000$ & 11.658 .000 \\
\hline Shade & 6.800 & 6,400 & 6,170 & $6,083,000$ & $5.515,000$ & $6,025,000$ \\
\hline Total & 23,200 & 22,600 & 22,540 & $33,533,000$ & $31,952,000$ & $31,056,000$ \\
\hline
\end{tabular}

The impact of the world wal on onr tobace industry was already bximg folt in 1941 and will surely be greater in 1942. First of all, labol hecame scarce and high priced because of the location of refense industries in the Valley. These fims paid wages the tobaceo farmer (o)lil not hope to meet.

Prices of materials. machinery, sharle cloth. fertilizers. etc.. have besm alimbing. ('ertain kinds of fertilizer materials which the to-

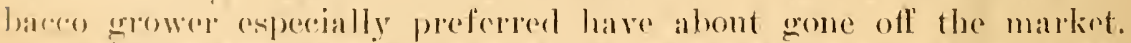

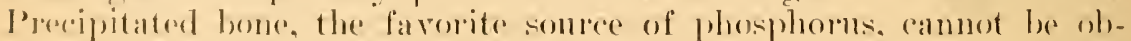

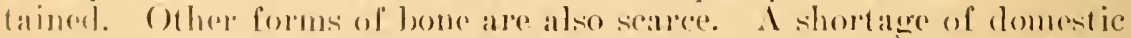
someres of petash was anticipated hut has not developert. There soents to bo (onough domestic sulfate of potash and rottonhull ashes

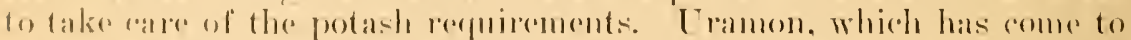

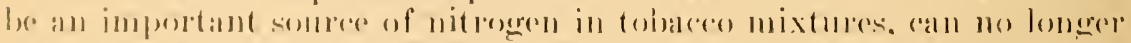

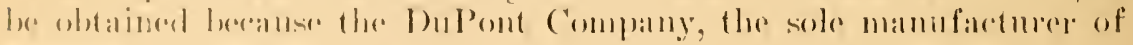


this material, has been obliged to turn so much of its chemical producing capacity to war chemicals. The effect of dislocations of freight and ocean transport on the other materials cannot be predicted at this time.

Since practically all Connecticut-grown tobacco is used domestically, the loss of foreign markets has no effect on it. The cutting off of Sumatra by war in the Pacific, however, may have a profound effect on our Shade industry. From one-third to one-half of the cigars produced in America are wrapped with Sumatra Leaf. There is now a large supply in this country but, if the war should continue to isolate Sumatra until this supply runs out, other sources of cigar wrappers must be found, and the logical substitute is Connecticut Valley Shade. If manufacturers should all turn to Shade the acreage could be almost doubled.

Detailed or summary reports on some of the projects under way at the Substation are presented in the following pages.

\section{THE RELATIVE CROP-PRODUCING CAPACITY OF UREA AND COTTONSEED MEAL}

The crop-producing capacity of any nitrogenous fertilizer is related to the nitrate concentration which it can develop and maintain in the soil during a relatively short period, from mid-June until early August. Very little nitrate is needed by the tobacco plants previous to this time and any that is supplied after this periodwhen the crop is already mature or harvested-is obviously wasted. Measurements of the concentration of nitrates in the soils to which such materials have been applied should, therefore, give the first indication of crop-producing efficiency. Such measurements were made at weekly intervals for four years (1932-35) at the Substation on tobacco plots treated with single nitrogen carriers. The results were published in Conn. Sta. Bul. 386, pp. 552-574. Comparing the cottonseed meal figures with those for urea (Table 13 of that report) we find that the average concentration of nitrate in the soil between June 18 and August 13 was 37 pounds per acre for cottonseed meal and 58 pounds for urea, i. e., cottonseed meal was much less effective than urea in its nitrate-producing capacity during these critical few weeks.

That more nitrate nitrogen is liberated from urea than from cottonseed meal and that the crop is able to utilize more of it is also indicated by lysimeter experiments which have been carried on here since 1929. In the lysimeter tests all nitrate nitrogen which is removed from the soil, either by leaching or by the growing crop cluring the year, is accurately measured.

Results of these 1940-41 lysimeter studies in nitrogen remoral by the crop and by leachate are given for urea and cottonseed meal 
in Table 3.1 This table shows that, starting with the same amount of nitrogen supplied in the fertilizer, a greater percentage was always recovered in the crop and that the total recovery (crop and leaching) was also always higher for urea.

In another series of lysimeter tests, 200 pounds per acre of nitrogen, in urea and cottonseed meal, were added to the soil annually for nine years. This was cropped to tobacco. The arerage annual

Table 3. Remonal of Nitrate Nitrogen by Crop and by Leaching in 12 Monthe, 1940-41. Comparison of Urea and Cottonseen Meal in LYSIMETERS.

\begin{tabular}{|c|c|c|c|c|}
\hline \multirow{2}{*}{$\begin{array}{l}\text { Pounds of nitrogen } \\
\text { added in } \\
\text { fertilizer } \\
\end{array}$} & \multirow[b]{2}{*}{ Nitrogen carrier } & \multicolumn{3}{|c|}{ Pounds of nitrogen recovered } \\
\hline & & $\begin{array}{c}\text { In } \\
\text { crop }\end{array}$ & $\begin{array}{l}\text { Leached as } \\
\text { nitrate }\end{array}$ & Total \\
\hline 0 & None & $3 \hat{3}$ & 47 & 80 \\
\hline 120 & $\begin{array}{l}\text { Urea } \\
\text { Cottonseed meal }\end{array}$ & $\begin{array}{l}91 \\
65\end{array}$ & $\begin{array}{l}58 \\
68\end{array}$ & $\begin{array}{l}149 \\
133\end{array}$ \\
\hline 160 & $\begin{array}{l}\text { Urea } \\
\text { Cottonseed meal }\end{array}$ & $\begin{array}{r}100 \\
77\end{array}$ & $\begin{array}{l}77 \\
73\end{array}$ & $\begin{array}{l}177 \\
150\end{array}$ \\
\hline 200 & $\begin{array}{l}\text { Urea } \\
\text { Cottonseed meal }\end{array}$ & $\begin{array}{r}130 \\
85\end{array}$ & $\begin{array}{l}90 \\
84\end{array}$ & $\begin{array}{l}220 \\
169\end{array}$ \\
\hline
\end{tabular}

removal of nitrogen (nitrate nitrogen in the leachate and total nitrogen in the plants) was 165 pounds for mea, 145 pounds for cottonseed meal and 47 pounds where no nitrogen was applied as fertilizer. We may assume that the 95 pounds (145 minus 47 ) of the nitrogen derived from cottonsed meal was sufficient to raise a normal cropl. Since 200 pomnds of nitrogen as urea libexated 118 pomms in excess of soil probluction of avalable nitrogen, then 166 pounds of nitrogen added in this material comld supply the reguired 98 pounds. 'Tlums, in this test. urea was about 20 percent more efficient than cottonseed mas in proviling nitrates for crop nse.

()n the field plots mentioned in the first paragraph in this section, the (erop) lertilized with urea was always lareer than that on the

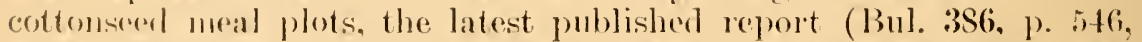
of this sitation) showing an average ammal merease of 100 pomols

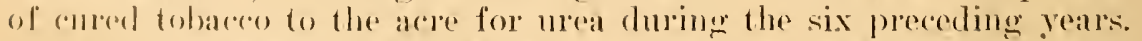
'The tobareen on the mea plots, however, was inclined to be too dark and heary for best quality. Since this objectionable characteristic often has bern obsererel on plots which were too heavily fertilized with nitroeren leom any somlere, it was natmal to conclude that the

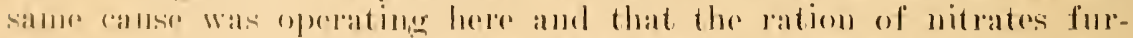

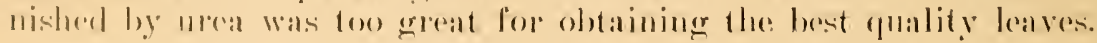

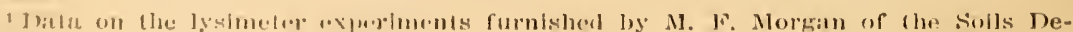
pistrimint. 
Assuming that this conclusion was correct, it seemed desirable to determine by field tests the relative efficiency of the two materials. If 200 pounds of nitrogen to the acre in cottonseed meal be regarded as the standard amount for growing a normal crop of tobacco, how much nitrogen in urea should be used to produce the same results?

To answer this question a series of 18 one-thirtieth acre plots was laid ont in 1937, with six different treatments in triplicate. The only differences in the fertilizer applications to these plots were in the quantity and source of nitrogen, all other fertilizer ingredients being kept constant. The various nitrogen treatments were:

150 pounds $N$ in urea

150 pounds $\mathrm{N}$ in cottonseed meal

175 pounds $\mathrm{N}$ in urea
175 pounds $\mathrm{N}$ in cottonseed meal

200 pounds $N$ in urea

200 pounds $\mathrm{N}$ in cottonseed meal

All plots received the same cultural treatment and were grown and harvested in the customary way for Havana Seed tobacco. The cured leaves were graded and weighed in the Station warehouse and the grades computed to a single figure (grade index ${ }^{1}$ ) from the

Table 4. Efficiency of Urea Compared with Cottonseed Meal. Four Years' SumMary of Yields and Grading.

\begin{tabular}{|c|c|c|c|c|c|c|c|c|c|c|c|}
\hline \multirow{2}{*}{ Material } & \multirow{2}{*}{$\begin{array}{c}\text { Lbs. N } \\
\text { per } \\
\text { acre } \\
\end{array}$} & \multicolumn{5}{|c|}{ Acre yield } & \multicolumn{5}{|c|}{ Grade index } \\
\hline & & 1937 & 1939 & 1940 & 1941 & Av. & 1937 & 1939 & 1940 & 1941 & AV. \\
\hline \multirow{3}{*}{ Urea } & \multirow{3}{*}{150} & $\overline{1706}$ & $\overline{1803}$ & 1506 & 1894 & \multirow{3}{*}{1843} & .302 & .373 & .294 & .405 & \multirow{3}{*}{.365} \\
\hline & & 2045 & 1916 & 1532 & 2206 & & .367 & .393 & .349 & .407 & \\
\hline & & 2073 & 1940 & 1444 & 2038 & & .366 & .392 & .336 & .397 & \\
\hline \multirow{3}{*}{ Urea } & \multirow{3}{*}{175} & 2095 & 1940 & 1495 & 2116 & \multirow{3}{*}{1924} & .396 & .391 & .349 & .429 & \multirow{3}{*}{.369} \\
\hline & & 2152 & 2058 & 1490 & 2134 & & .380 & .379 & .283 & .377 & \\
\hline & & 2077 & 2092 & 1419 & 2014 & & .369 & .397 & .291 & .381 & \\
\hline \multirow{3}{*}{ Urea } & \multirow{3}{*}{200} & 1957 & 2005 & 1500 & 2315 & \multirow{3}{*}{1995} & .335 & .398 & .345 & .448 & \multirow{3}{*}{.380} \\
\hline & & 2273 & 2046 & 1688 & 2346 & & .380 & .373 & .355 & .396 & \\
\hline & & 2162 & 2000 & 1523 & 2123 & & .403 & .384 & .341 & .395 & \\
\hline \multirow{3}{*}{ C. S. M. } & \multirow{3}{*}{150} & $\overline{1849}$ & 1875 & 1510 & 1916 & \multirow{3}{*}{1803} & .326 & .376 & .359 & .364 & \multirow{3}{*}{.355} \\
\hline & & 2033 & 1872 & 1605 & 2058 & & .326 & .388 & .380 & .385 & \\
\hline & & 1790 & 1831 & 1430 & 1864 & & .342 & .347 & .355 & .319 & \\
\hline \multirow{3}{*}{ C. S. M. } & \multirow{3}{*}{175} & 2004 & 1830 & $\overline{1514}$ & 1857 & \multirow{3}{*}{1842} & .366 & .358 & .370 & .377 & \multirow{3}{*}{.360} \\
\hline & & 2091 & 1937 & 1581 & 2147 & & .345 & .383 & .368 & .385 & \\
\hline & & 1916 & 1823 & 1515 & 1886 & & .345 & .361 & .328 & .340 & \\
\hline \multirow{3}{*}{ C. S. M. } & \multirow{3}{*}{200} & 2355 & 1924 & 1504 & 2250 & \multirow{3}{*}{1926} & .384 & .368 & .347 & .418 & \multirow{3}{*}{.368} \\
\hline & & 2227 & 1891 & 1582 & 2178 & & .380 & .391 & .321 & .408 & \\
\hline & & 1988 & 1770 & 1495 & 1947 & & .360 & .349 & .306 & .382 & \\
\hline
\end{tabular}

1 Grade index is a firure which represents the relative value of a lot of tobacco computed on the percentage weight of each gradle of leaves in the lot and the relative values of these grades. Assuming that the light wrapper is the perfect leaf of Havana Seed tobacco, we assion to it a value of 100 . The other grades are assigned values of the same proportion of 100 as their market value was to the price of the light wrapper when this system was established. Thus medium wrappers have a value of 60 ; long seconds ( 19 inches or more) are 60 ; short seconds (15 and 17 inches) are 30 ; long darks are $30:$ dark stemming (short darks of 15 and 17 inches) are 20 ; fillers and brokes are 10 . It is true that the values of these grades have fluctuated considerably during the 15 years that we have used this system of comparing lots of tobacco but, in order to be able to average results over a period of years, it seems advisable to retain the same system for the present. To obtain the grade index figure the percentage of each grade in a lot of tobacco is multiplied by the relative valies noted above and the products are added. 
weights and relative ralues of each grade. The results are presented in Table $t$ for the years $1937,1939,1940$ and 1941 . The crop of 1938 was omitted from the calculations because the extreme weather conditions of that year resulted in such poor quality that for the most part it was not worth sorting.

From the averages (bold face type) in this table the following observations may be made:

1. Each increase in quantity of nitrogen in the fertilizer, whether in urea or in cottonseed meal, produced an increase in yield.

2. Each increase in fertilizer nitrogen, regardless of source, inproved the grade index.

3. When the quantity of nitrogen was the same, both the yield and index were always higher for urea.

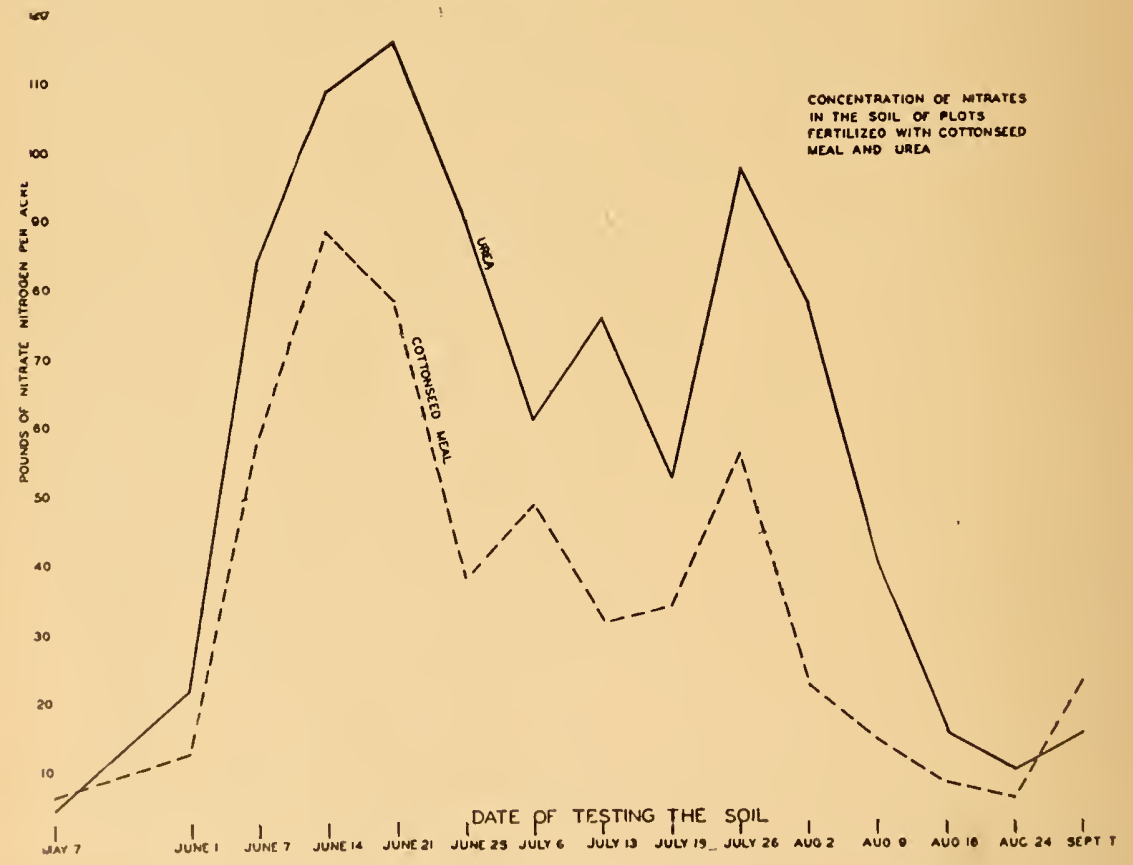

lijgure 1. Cinscentration of nitrate in soils of urea and cottonsecd meal plots during seitsoll of 1937.

4. With 17is pommls ol nitrogen in mrea practically the same yidd and grade index were oldained as with 200 poumds of nitrogen in rottonserent meal.

5. Ithen the urea nitheren was reduced to 1.50 pounds, howerer, the areatage yeded was considerably below that of 200 pounds in cot(o) 
out of the four years, however, 150 pounds in urea was as good as 200 in cottonseed meal.

The results from four years of this trial indicate, therefore, that urea nitrogen is at least 14 percent more efficient than cottonseed meal nitrogen in its crop-producing capacity.

During one year of this field test (1937) the nitrate concentration in the soil was determined at weekly intervals. The average of all urea plots, contrasted with the cottonseed meal plots, is graphically presented in Figure 1, where it will be seen that urea consistently accumulated more nitrate than did cottonseed meal. The average concentration of nitrates in all urea plots, from June 14 to August 16, was 73.5 pounds of nitrogen per acre, contrasted with 41.6 for the cottonseed meal plots. This suggests that the better yield on the urea plots was due to the greater supply of nitrates available in the soil during the critical period. It will be observed, however, that the difference in nitrate concentration is greater than the percentage increase in crop production, showing that the crop return is not exactly proportional to the quantity of nitrates in the soil. This may be due to the presence of other growth materials in cottonseed meal or to the fact that the yields here are too close to the upper limit of possible crop response to increased fertilizer; i. e., the law of diminishing returns is operating. A more correct conclusion may be drawn by comparing the " 175 pound urea" plots with the " 200 pound cottonseed meal" plots. These two gave nearly the same crop response, as already noted. The average concentration of the former during the summer was 53 pounds of nitrate-nitrogen per acre while the latter was 48 pounds. This makes a difference of 5 pounds, which is probably too smail to be of significance in these field tests.

Comparative Grading. An important question to the handler of tobacco is: what effect does the substitution of urea for cottonseed meal have on the percentage of grades when the leaves are sorted?

The sorting records for the crop of 1941 on these plots are shown in Table 5 .

This year is selected because it was the final vear of the test and should, therefore, show the maximum results of any cumulative effects from continuous use of each fertilizer. Moreover, it was a favorable growing season and resulted in the most regular crop of the series. The data presented in this table show that, contrary to our previous impression, urea did not increase the percentage of dark grades nor decrease the percentage of the better light grades. For the same quantity of fertilizer nitrogen, therefore, the grade index was uniformly higher for urea. No burn tests were made this year because many previous trials at this Station (see particularly Bul. 299, p. 172) have demonstrated that the fire-holding capacity is not affected by the use of mea. Divergent opinions have been ex- 
pressed by buyers. packers and manufacturers as to the effect of urea on the more intungible qualities such as taste. aroma. finish and the like. Since there is no known method of measuring these factors of quality, and. moreover, opinion is so diversified, this question does not appear close to solution in the near future.

Table 5. Yield and Grading Records of Urea Erficiency Comparen with Cottonseed Meal Plots. Crop of 1941.

\begin{tabular}{|c|c|c|c|c|c|c|c|c|c|c|c|c|c|c|c|}
\hline \multirow[t]{2}{*}{ Material 1} & \multirow{2}{*}{$\begin{array}{c}\text { Lbs. N } \\
\text { per } \\
\text { acre }\end{array}$} & \multirow{2}{*}{$\begin{array}{c}\text { Plot } \\
\text { no. }\end{array}$} & \multicolumn{2}{|c|}{$\begin{array}{l}\text { Yield, Ibs. } \\
\text { per acre }\end{array}$} & \multicolumn{8}{|c|}{ Percentage of grades } & \multicolumn{2}{|c|}{$\begin{array}{l}\text { Grade } \\
\text { index }\end{array}$} & \multirow{2}{*}{$\begin{array}{l}\text { Crop } \\
\text { index }\end{array}$} \\
\hline & & & Plot & Av. & $\mathrm{L}$ & $M$ & LS & $5 S$ & $L D$ & DS & $F$ & 8 & Plot & $\overline{A v}$. & \\
\hline Urea & 150 & $\begin{array}{l}>0 \\
\text { N70-1 } \\
\text { N70-2 }\end{array}$ & $\begin{array}{l}1894 \\
2206 \\
2038\end{array}$ & 2046 & $\begin{array}{l}2 \\
4 \\
2\end{array}$ & $\begin{array}{l}2 \\
2 \\
2\end{array}$ & $\begin{array}{l}39 \\
34 \\
37\end{array}$ & $\begin{array}{l}2 \\
3 \\
3\end{array}$ & $\begin{array}{l}38 \\
42 \\
37\end{array}$ & $\begin{array}{l}2 \\
1 \\
4\end{array}$ & \begin{tabular}{r|}
9 \\
8 \\
12
\end{tabular} & $\begin{array}{l}6 \\
6 \\
3 \\
\end{array}$ & $\begin{array}{l}.405 \\
.407 \\
.397\end{array}$ & .403 & 824.54 \\
\hline Urea & 175 & $\begin{array}{l}\mathrm{N} 71 \\
\text { N71-1 } \\
\text { N71-2 }\end{array}$ & $\begin{array}{l}2116 \\
2134 \\
2014\end{array}$ & 2088 & $\begin{array}{l}6 \\
1 \\
1\end{array}$ & $\begin{array}{l}2 \\
1 \\
1\end{array}$ & $\begin{array}{l}37 \\
31 \\
34\end{array}$ & $\begin{array}{l}2 \\
7 \\
4\end{array}$ & $\begin{array}{l}\overline{37} \\
46 \\
43\end{array}$ & $\begin{array}{l}2 \\
2 \\
3\end{array}$ & $\begin{array}{r}9 \\
11 \\
10\end{array}$ & $\begin{array}{l}5 \\
1 \\
4\end{array}$ & $\begin{array}{l}.429 \\
.377 \\
.381\end{array}$ & 396 & 826.85 \\
\hline Urea & 200 & $\begin{array}{l}\mathrm{N} 72 \\
\mathrm{~N} 72-1 \\
\mathrm{~N} 72-2 \\
\end{array}$ & $\begin{array}{r}2315 \\
2346 \\
2123 \\
\end{array}$ & 2261 & $\begin{array}{l}5 \\
3 \\
1\end{array}$ & $\begin{array}{l}1 \\
2 \\
1\end{array}$ & $\begin{array}{l}\overline{43} \\
36 \\
38\end{array}$ & $\begin{array}{l}2 \\
2 \\
3\end{array}$ & $\begin{array}{l}\overline{39} \\
37 \\
41\end{array}$ & $\begin{array}{l}1 \\
1 \\
3\end{array}$ & $\begin{array}{r}7 \\
8 \\
11\end{array}$ & $\begin{array}{r}2 \\
11 \\
2\end{array}$ & $\begin{array}{l}.448 \\
.396 \\
.395 \\
\end{array}$ & 413 & 933. \\
\hline C. S. M. & 150 & $\begin{array}{l}N 73 \\
N 73-1 \\
N 73-2 \\
\end{array}$ & $\begin{array}{l}1916 \\
2058 \\
1864 \\
\end{array}$ & 1946 & $\begin{array}{r}1 \\
2 \\
. \\
\end{array}$ & $\begin{array}{r}1 \\
1 \\
. \\
\end{array}$ & $\begin{array}{l}32 \\
34 \\
26\end{array}$ & $\begin{array}{l}4 \\
4 \\
2 \\
\end{array}$ & $\begin{array}{l}39 \\
40 \\
40\end{array}$ & $\begin{array}{l}4 \\
4 \\
5 \\
\end{array}$ & $\begin{array}{l}11 \\
10 \\
12 \\
\end{array}$ & $\begin{array}{r}8 \\
5 \\
15 \\
\end{array}$ & $\begin{array}{l}.364 \\
.385 \\
.319 \\
\end{array}$ & .356 & 692.78 \\
\hline C. S. M. & 175 & $\begin{array}{l}N 74 \\
N 74-1 \\
N 74-2 \\
\end{array}$ & $\begin{array}{l}1857 \\
2147 \\
1886 \\
\end{array}$ & 1963 & $\begin{array}{l}2 \\
2 \\
. .\end{array}$ & $\begin{array}{l}2 \\
3\end{array}$ & $\begin{array}{l}\overline{33} \\
31 \\
26\end{array}$ & $\begin{array}{l}2 \\
4 \\
3\end{array}$ & $\begin{array}{l}37 \\
43 \\
50\end{array}$ & $\begin{array}{l}6 \\
3 \\
4\end{array}$ & $\begin{array}{l}\overline{12} \\
10 \\
13\end{array}$ & $\begin{array}{l}6 \\
4 \\
4\end{array}$ & $\begin{array}{l}.377 \\
.385 \\
.340 \\
\end{array}$ & .367 & 720.42 \\
\hline C. S. M. & 200 & $\mid \begin{array}{l}N 75 \\
\text { N75-1 } \\
\text { N75-2 }\end{array}$ & $\begin{array}{l}2250 \\
2178 \\
1947 \\
\end{array}$ & 2125 & $\begin{array}{l}4 \\
3 \\
1\end{array}$ & $\begin{array}{l}4 \\
2 \\
2\end{array}$ & \begin{tabular}{|l|}
35 \\
36 \\
35
\end{tabular} & $\begin{array}{l}2 \\
3 \\
3 \\
\end{array}$ & \begin{tabular}{|l|}
41 \\
41 \\
38
\end{tabular} & $\begin{array}{l}1 \\
3 \\
6\end{array}$ & $\left|\begin{array}{r}8 \\
9 \\
11\end{array}\right|$ & $\begin{array}{l}5 \\
3 \\
4\end{array}$ & $\begin{array}{l}.418 \\
.408 \\
.382\end{array}$ & .403 & 6.38 \\
\hline
\end{tabular}

1 Pelative Crop Values.

$\begin{array}{ll}200 \text { Urea }=109.0 & 200 \text { C. S. M. }=100.0 \\ 175 \text { Urea }=96.6 & 175 \text { C. S. M. }=84.1 \\ 150 \text { Urea }=96.3 & 150 \text { C. S. M. }=80.9\end{array}$

\section{THE EFFECT OF SOME SOURCES OF PHOSPHORUS ON CIGAR LEAF TOBACCO.}

\section{'T. R. SWANmark, M. F. Morgax . IND P'. J. Andmerson}

In the fertilization of tobace in the Connecticut Valley growers have been accustomed to use bone phosphates in one form or another. Preceipitated bone is probably the most commonly med material. Eanlier investigations by Jenkins in 1914 (Comn. Stia. Bul. 180:-8-30) and later by Nelson and Anderson (Tobaceo Sta. Bul. 5:17-2-t) showed faverable results with precipitated bone. The ereater portion

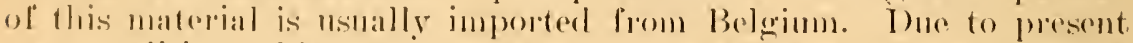
war conditions this somrere of supply is suspended. Even a second rhoice of bone phosphates, such as raw bone and steamed bone, soon may mot be available in sullicient quantities to meet the demand.

In anticipation of such shortage of bene phosphates, an experimont on field plots at the Windson Subatation was begun with the object of limbing whethere other phosphates combl be sulistituted. 
Included in the materials, in addition to precipitated bone and steamed bone, were concentrated superphosphate (triple superphosphate), calcium metaphosphate, potassium metaphosphate and potassium calcium metaphosphate. These were furnished by the Tennessee Valley Authority. The last mentioned material was added to the tests in 1941, while the others were included in the experiment when it was begun in 1940 .

The field allotted to the experiment had been used for vegetable crops for many year's previous to 1940 and possessed normal fertility. Therefore, it was not anticipated that there would be symptoms of phosphorus deficiency on plots included in the test, even where the fertilizer contained no special carrier of phosphorus.

The various phosphatic materials, each furnishing 116 pounds $\mathrm{P}_{2} \mathrm{O}_{5}$ per acre, were added to one common fertilizer formula that included uramon, soybean oil meal and nitrate of soda as carriers of nitrogen and potash in the form of sulfate of potash. These materials were selected because of very low content or almost entire lack of $\mathrm{P}_{2} \mathrm{O}_{5}$. Lime, magnesium sulfate (Emjeo) and landplaster were also included for the purpose of establishing acid-basic balance and distributing an exact and uniform amount of plant nutrients among the treatments. All tests were carried out in quadruplicate (onefortieth acre) plots, except the potassium calcium metaphosphate. For tests on the latter material, the size of the field permitted inclusion of only two plots.

The summer of 1941 was a favorable growing season and uniform growth was observed on the entire field. In mid-season, however, it was noticed that tobacco on the calcium metaphosphate plots had a more luxuriant spread and was taller than that under other treatments.

The following general remarks were made at the time of sorting.

No P-carrier: short, dark, coarse, not veiny.

Precipitated bone: good to very good quality, not veiny.

Triple superphosphate: good, veiny, slightly reddish.

Steamed bone: good, but a little heavy, slightly veiny.

Ca-metaphosphate: very good quality, slightly veiny.

$\mathrm{K}$-metaphosphate: very good quality, slightly veiny.

$\mathrm{K}$, Ca-metaphosphate: very good but short, not veiny.

The yield and grading records will be found in Table 6 .

In examining the yield data it is apparent that, in the second year of the experiment, there was no difficulty in obtaining heavy yields on this particular test field, even with no special phosphorus carrier.

Calcium metaphosphate and triple superphosphate produced about 7 percent higher yields than the check; precipitated bone about 5 percent higher, while steamed bone equalled the check. However, 
none of these deviations from the yields of the check plots might be considered significant.

On the other hand, potassim metaphosphate and potassium calcium metaphosphate produced an average of 15 percent lower vields than the control plots. It is of interest to keep in mind that potassium is the carrier of phosphorus in both these materials. Potassium calcium metaphosphate contains only about 4 percent $\mathrm{CaO}$ and orer 35 percent $\mathrm{K}=\mathrm{O}$; that is, the same as for potassium metaphosphate.

Table 6. Yield and Grading Records of Phosphorus Plots. Crol of 1941.

\begin{tabular}{|c|c|c|c|c|c|c|c|c|c|c|c|c|c|}
\hline \multirow[t]{2}{*}{ Treatment } & \multirow{2}{*}{ Plot no. } & \multicolumn{2}{|c|}{$\begin{array}{l}\text { Yield lbs. } \\
\text { per acre }\end{array}$} & \multicolumn{8}{|c|}{ Percentage of grades } & \multicolumn{2}{|c|}{ Grade index } \\
\hline & & Piot & Av. & $\mathrm{L}$ & $\bar{M}$ & LS & 55 & $L D$ & DS & $\mathrm{F}$ & $B$ & Plot & Av. \\
\hline $\begin{array}{l}\text { No phosphorus } \\
\text { carrier }\end{array}$ & $\begin{array}{l}\text { P11 } \\
\text { P11-1 } \\
\text { P11-2 } \\
\text { P11-3 }\end{array}$ & $\begin{array}{l}2503 \\
2300 \\
2040 \\
2564\end{array}$ & 2352 & $\ddot{2}$ & $\begin{array}{l}1 \\
2 \\
2 \\
4\end{array}$ & $\begin{array}{l}38 \\
36 \\
33 \\
40\end{array}$ & $\begin{array}{l}3 \\
3 \\
4 \\
3\end{array}$ & $\begin{array}{l}40 \\
47 \\
45 \\
41\end{array}$ & $\begin{array}{l}1 \\
1 \\
2 \\
1\end{array}$ & $\begin{array}{l}9 \\
8 \\
8 \\
7\end{array}$ & $\begin{array}{l}1 \\
3 \\
4 \\
1\end{array}$ & $\begin{array}{l}.403 \\
.391 \\
.393 \\
.436\end{array}$ & .4 \\
\hline $\begin{array}{l}\text { Precipitated } \\
\text { bone }\end{array}$ & $\begin{array}{l}\overline{\mathrm{P} 12} \\
\mathrm{P} 12-1 \\
\mathrm{P} 12-2 \\
\mathrm{P} 12-3\end{array}$ & $\begin{array}{l}2490 \\
2599 \\
2657 \\
2082\end{array}$ & 2457 & $\begin{array}{l}4 \\
2 \\
4\end{array}$ & $\begin{array}{c}3 \\
2 \\
3 \\
\ldots\end{array}$ & $\begin{array}{l}31 \\
39 \\
41 \\
33\end{array}$ & $\begin{array}{l}3 \\
2 \\
2 \\
4 \\
\end{array}$ & $\begin{array}{l}48 \\
44 \\
41 \\
47 \\
\end{array}$ & $\begin{array}{l}1 \\
1 \\
2 \\
2\end{array}$ & $\begin{array}{r}9 \\
8 \\
7 \\
11 \\
\end{array}$ & $\begin{array}{l}1 \\
2 \\
2 \\
3\end{array}$ & $\begin{array}{l}.409 \\
.416 \\
.442 \\
.369\end{array}$ & \\
\hline $\begin{array}{l}\text { Triple super- } \\
\text { phosphate }\end{array}$ & $\begin{array}{l}\text { P13 } \\
\text { P13-1 } \\
\text { P13-2 } \\
\text { P13-3 }\end{array}$ & $\begin{array}{l}2403 \\
2602 \\
2694 \\
2369\end{array}$ & 2517 & $\begin{array}{l}1 \\
2 \\
2\end{array}$ & $\begin{array}{l}2 \\
3 \\
2\end{array}$ & $\begin{array}{l}40 \\
39 \\
38 \\
42\end{array}$ & $\begin{array}{l}3 \\
3 \\
2 \\
4\end{array}$ & $\begin{array}{l}43 \\
39 \\
48 \\
43\end{array}$ & $\begin{array}{l}1 \\
1 \\
1 \\
1\end{array}$ & $\begin{array}{l}8 \\
7 \\
7 \\
7\end{array}$ & $\begin{array}{l}2 \\
6 \\
2 \\
1\end{array}$ & $\begin{array}{l}.412 \\
.413 \\
.409 \\
.415\end{array}$ & .4 \\
\hline Steamed bone & $\begin{array}{l}\text { P14 } \\
\text { P14-1 } \\
\text { P14-2 } \\
\text { P14-3 }\end{array}$ & $\begin{array}{l}2511 \\
2183 \\
2335 \\
2348\end{array}$ & 2344 & $\begin{array}{l}3 \\
2 \\
1 \\
2\end{array}$ & $\begin{array}{l}2 \\
1 \\
2 \\
2\end{array}$ & $\begin{array}{l}36 \\
41 \\
44 \\
40\end{array}$ & $\begin{array}{l}2 \\
4 \\
2 \\
3 \\
\end{array}$ & $\begin{array}{l}46 \\
42 \\
38 \\
40\end{array}$ & $\begin{array}{l}1 \\
1 \\
1 \\
1\end{array}$ & $\begin{array}{l}9 \\
9 \\
7 \\
9\end{array}$ & $\begin{array}{c}1 \\
\cdots \\
5 \\
3\end{array}$ & $\begin{array}{l}.414 \\
.421 \\
.420 \\
.415 \\
\end{array}$ & \\
\hline $\begin{array}{l}\text { Calcium } \\
\text { metaphosphate }\end{array}$ & $\begin{array}{l}\text { P15 } \\
\text { P15-1 } \\
\text { P15-2 } \\
\text { P15-3 }\end{array}$ & $\begin{array}{l}2472 \\
2556 \\
2596 \\
2450\end{array}$ & 2519 & $\begin{array}{l}5 \\
6\end{array}$ & $\begin{array}{l}3 \\
3 \\
1 \\
4\end{array}$ & $\begin{array}{l}38 \\
35 \\
43 \\
40\end{array}$ & $\begin{array}{l}2 \\
3 \\
2 \\
2\end{array}$ & $\begin{array}{l}42 \\
42 \\
42 \\
33\end{array}$ & $\begin{array}{l}1 \\
1 \\
1 \\
3\end{array}$ & $\begin{array}{l}7 \\
9 \\
7 \\
7\end{array}$ & $\begin{array}{l}2 \\
1 \\
1 \\
2\end{array}$ & $\begin{array}{l}439 \\
.435 \\
.436 \\
.474\end{array}$ & .44 \\
\hline $\begin{array}{l}\text { Potassium } \\
\text { metaphosphate }\end{array}$ & $\begin{array}{l}\text { P16 } \\
\text { P16-1 } \\
\text { P16-2 } \\
\text { P16-3 }\end{array}$ & $\begin{array}{l}1984 \\
1809 \\
2350 \\
2141\end{array}$ & 2071 & 3 & $\begin{array}{c}6 \\
\ldots\end{array}$ & $\begin{array}{l}39 \\
30 \\
38 \\
35 \\
\end{array}$ & $\begin{array}{l}4 \\
2 \\
4 \\
4\end{array}$ & $\begin{array}{l}40 \\
41 \\
39 \\
48\end{array}$ & $\begin{array}{l}1 \\
3 \\
1 \\
1\end{array}$ & $\begin{array}{r}10 \\
15 \\
7 \\
11\end{array}$ & $\begin{array}{l}1 \\
9 \\
1 \\
1\end{array}$ & $\begin{array}{l}.421 \\
.339 \\
.443 \\
.380\end{array}$ & .39 \\
\hline $\begin{array}{c}\text { Potassium } \mathrm{Ca}- \\
\text { metaphosphate }\end{array}$ & $\begin{array}{l}\text { P17 } \\
\text { P17-1 }\end{array}$ & $\begin{array}{l}1944 \\
1883\end{array}$ & 1914 & $\begin{array}{l}5 \\
3\end{array}$ & $\begin{array}{l}3 \\
3\end{array}$ & $\begin{array}{l}38 \\
36\end{array}$ & $\begin{array}{l}3 \\
3\end{array}$ & $\begin{array}{l}39 \\
41\end{array}$ & $\begin{array}{l}1 \\
2\end{array}$ & $\begin{array}{r}9 \\
10\end{array}$ & 2 & $\begin{array}{l}.435 \\
.412\end{array}$ & .424 \\
\hline
\end{tabular}

Although reasonable yields are of importance in crop production with respect to leaf tobacco, quality is still more important. Of the materials tested, only the calcium metaphosphate produced tobacco deciderlly superior in grade to that of the control plots (average irrarle index .406, as compared with .4f6). In addition, it is noteworthy that calcimm metaphosphate produced about 12 percent less "darks" than the cherek.

'The other soures of phosphorus produced tobaceo of somewhat ligher grading than the control (two out of four plots of potassium metaphosphate reacherl higher indexes than the check). 'The varia- 
tion between treatments, however, is not much higher than the variation in values between plots.

If quantity to a certain extent makes up for quality, the crop index (product of yield figure and corresponding value of grade index) should give a conception of the return values of various treatments.

The following resumé, based on average crop indexes and giving a value of 100 to the control, presents an evaluation of the return from the use of the various sources of phosphorus. They may be referred to as relative crop values.

$\begin{array}{lr}\text { No phosphorus } & 100 . \\ \text { Steamed bone } & 101.6 \\ \text { Precipitated bone } & 105.2 \\ \text { Triple superphosphate } & 108.6 \\ \text { Calcium metaphosphate } & 117.6 \\ \text { Potassium metaphosphate } & 98.0 \mathrm{Av} \text {. of two good plots } \\ \text { Potassium metaphosphate } & 74.5 \mathrm{Av} \text {. of two inferior plots } \\ \text { Potassium metaphosphate } & 85.9 \mathrm{Av} \text {. of all four plots } \\ \text { Potassium calcium metaphosphate } & 85.0 \mathrm{Av} \text {. of two plots }\end{array}$

For comparison, a two-year average of corresponding values is given below (with the exception of potassium calcium metaphosphate, for which data of only one year values are available).

$\begin{array}{ll}\text { No phosphorus } & 100 \\ \text { Potassium metaphosphate } & 100 \text { (at best) } \\ \text { Steamed bone } & 101.9 \\ \text { Triple superphosphate } & 104.6 \\ \text { Precipitated bone } & 106.6 \\ \text { Calcium metaphosphate } & 113.6\end{array}$

These two-year averages agree closely with results of the present year, with the exception that the positions of precipitated bone and superphosphate are reversed. If it be recalled that the triple superphosphate had a tendency to produce an undesirable reddish cast of the cured leaf, this per se reduces the possible value of the material in cigar leaf production, in particular as regards wrapper tobacco.

Therefore, the rank of the phosphorus sources tested, considering their relative quality, would be as follows:
1. Calcium metaphosphate
2. Precipitated bone
3. Steamed bone
4. Potassium metaphosphate
5. Potassium calcium metaphosphate
6. Triple superphosphate

\section{Chemical Analyses}

Samples of tobacco grown with the various phosphorus carriers were collected from the replicates to make up one composite sample of long seconds and one of long darks per treatment. They were dried, ground to a fine powder and then analyzed with respect to 
content of phosphorus, potassium, calcium and magnesium. The results on phosphorus are shown in Table 7 .

It is seen.that the phosphoric acid content varies little, about half of one percent. 'Tobacco fertilized with precipitater bone and calcium metaphosphate contained the least phosphorus, particularly in the "seconds." In considering crop removal of phosphorus, however, we find in the following summary a rather uniform utilization of the phosphorus available in the soil.

Table 7. Phosphorus Content of Cured Tobacco. Air Dry Basis. CROP OF 1941.

\begin{tabular}{|c|c|c|c|c|}
\hline Source of phosphorus & Grade & Plot no. & $\begin{array}{l}\text { Percent } \\
\mathrm{P}_{2} \mathrm{O}_{5}\end{array}$ & $A v$ \\
\hline None & $\begin{array}{l}\mathrm{LS} \\
\mathrm{LD}\end{array}$ & $\overline{\mathrm{P}} 11$ & $\begin{array}{l}0.45 \\
0.55 \\
\end{array}$ & 0.50 \\
\hline Precipitated bone & $\begin{array}{l}\mathrm{LS} \\
\mathrm{LD} \\
\end{array}$ & P12 & $\begin{array}{l}0.41 \\
0.53 \\
\end{array}$ & 0.47 \\
\hline Triple superphosphate & $\begin{array}{l}\mathrm{LS} \\
\mathrm{LD}\end{array}$ & P13 & $\begin{array}{l}0.46 \\
0.57\end{array}$ & 0.52 \\
\hline Steamed bone & $\begin{array}{l}\mathrm{LS} \\
\mathrm{LD}\end{array}$ & P14 & $\begin{array}{l}0.43 \\
0.55\end{array}$ & 0.49 \\
\hline Calcium metaphosphate & $\begin{array}{l}\mathrm{LS} \\
\mathrm{LD}\end{array}$ & P15 & $\begin{array}{l}0.38 \\
0.52\end{array}$ & 0.45 \\
\hline Potassium metaphosphate & $\begin{array}{l}\mathrm{LS} \\
\mathrm{LD}\end{array}$ & P16 & $\begin{array}{l}0.49 \\
0.53\end{array}$ & 0.51 \\
\hline $\begin{array}{l}\text { Potassium calcium metaphos- } \\
\text { phate }\end{array}$ & $\begin{array}{l}\mathrm{LS} \\
\mathrm{LD}\end{array}$ & P17 & $\begin{array}{l}0.50 \\
0.52\end{array}$ & 0.51 \\
\hline
\end{tabular}

Average removal of phosplioric acid ( $\left.\mathrm{P}_{\mathrm{O}} \mathrm{O}_{\mathbf{s}}\right)$ by yield of leaves from various phosphorus treatments. ${ }^{1}$

Check

Precipitated bone

Triple superphosphate

Steaned bonc

Calcium metaphosphate

Potassium metaphosphate

Potassium calcium metaphosphate
11.76 pounds per acre

11.55 pounds per acre

13.09 pounds per acre

11.49 pounds per acre

11.33 pounds per acre

10.56 pounds per acre

9.76 pounds per acre

The check, precipitated home, steamed bone and calcimm metaphesphate eome readily within the range of arepage phosphorts re-

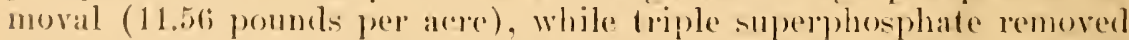
more, and the wo potash phosphates removed less, than the arerace.

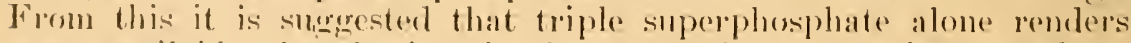
more avalable phosphoric areid than any of the materials testerl.

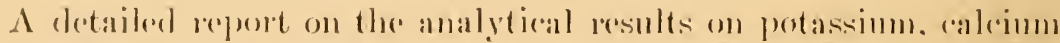

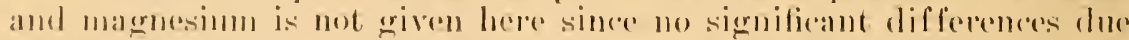
to teratments were apparent. 'The average potash (KaO) content

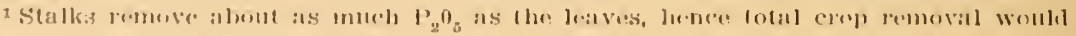

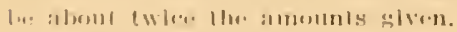


was $4.09 \pm 0.206$ percent, calcium ( $\mathrm{CaO}) 5.75 \pm 0.1$ percent and magnesia ( $\mathrm{MgO}) 1.70 \pm 0.066$ percent. Analytical results give little or no explanation, in particular to the behavior of calcium metaphosphate which ranked the highest in the present investigation. It is possible that this material has a favorable influence on rendering other nutrients more available, and this influence may be extended to reactions in the plant tisstues.

\section{THE EFFECT OF SOURCE ON MAGNESIUM ABSORPTION BY TOBACCO}

\section{T. R. Swanbacis}

The role of magnesia and its place in cigar leaf production are rather well established through extensive work at this Station. (See Bulls. 350 and 386). The tobacco grower in the Connecticut Valley who avails himself of the soil testing service keeps informed on the status of magnesia content in his land. Although many of the materials used in tobacco fertilizers contain more or less magnesia, it is often necessary to include a special carrier. Under conditions where it has been advisable to use lime containing magnesia. the question has often been asked whether magnesian limestone (dolomite) or hydrated magnesian lime is more effective in producing the desired results in the same season that materials are applied.

In an attempt to find an answer to this question a field was selected which was low in fertility (soil reaction $\mathrm{pH} 4.8$ ) and which had not grown tobacco for at least 15 years. The field was divided into four one-twentieth acre plots, one of which did not receive any liming material.

The remaining three plots were treated as follows:

1. Hydrated magnesian lime

2. Magnesian limestone

3. SLandplaster ${ }^{1}$

3. \{plus Emjeo (Anhydr. $\mathrm{MgSO}_{4}$ )

$\begin{array}{ccc}\begin{array}{c}\text { Pounds } \\ \text { Material }\end{array} & \text { CaO acre of } & \text { MgO } \\ 800 & 300 & 200 \\ 1000 & 300 & 200 \\ 1000 & 300 & 10\} \\ & & 190\end{array}$

The entire field was fertilizerl uniformly with an 8-4-8 mixture at the rate of 2,500 pounds per acre. Tobacso was planted crosswise to the lime applications.

Vigorous growth was observed on the three treated plots, while the size of plants on the check plot was noriceably smaller.

While the main purpose of growing the crops was to determine the content of magnesium and possibly calcium in the cured leares from the various applications, it may be of interest to learn about the

${ }^{1}$ Landplaster and magnesium sulfate were included as a treatment for comparing a neutral supply of $\mathrm{CaO}$ and $\mathrm{MgO}$ versus the lime materials which offset a part of the soil acidity. 
effect on rield and grading. On the sorting table all the tobacco from this field was considered to be of rery good quality, with satisfactory texture and color, except for the plot recciving landplaster (calcium sulfate) and magnesium sulfate. Here, the fillers (leares closest to the ground) were of a blackish color (known to the trade as "black tobacco") and. in general, the tobacco from this treatment: was inferior in quality to the control and the two lime treatments. In this connection, it should be pointed out that landplaster is not recommended for application to tobacco land that is too acid. Is has been pointed out earlier, (Bul. 350:47t and Bul. 444:260), landplaster may be employed only on tobacco soils having a satisfactory reaction $(\mathrm{pH})$.

Table 8 lists vield and grading data. In line with field observations, it is found that the control plot produced the lowest vield, while hydrated lime and landplaster produced almost identical yields, about 300 pounds per acre more than the control, and magnesian limestone produced about 480 pounds more than the control.

The grading, as indicated by the grade indexes, again shows that the landplaster treatment falls below the rest in quality.

Table 8. Yield and Grading Records of Magnesian Lime Test. Crop of 1941.

\begin{tabular}{|c|c|c|c|c|c|c|c|c|c|c|c|}
\hline \multirow{2}{*}{ Treatment } & \multirow{2}{*}{$\begin{array}{l}\text { Yield } \\
\text { per } \\
\text { acre }\end{array}$} & \multicolumn{8}{|c|}{ Percentage of grades } & \multicolumn{2}{|c|}{ Index } \\
\hline & & $L$ & $M$ & LS & SS & LD & DS & $F$ & $B$ & Grade & Crop \\
\hline $\begin{array}{l}\text { Control } \\
\text { Hydrated } \mathrm{Mg}\end{array}$ & 1978 & 8 & 2 & 35 & 2 & 38 & 3 & 10 & 2 & .440 & 870.3 \\
\hline $\begin{array}{l}\text { lime } \\
\text { Landplaster- }\end{array}$ & 2295 & 10 & 3 & 40 & 1 & 35 & 1 & 9 & 1 & .478 & 1097.0 \\
\hline $\mathrm{Em}$ & 2280 & 2 & 2 & 36 & 1 & 41 & 2 & 12 & 4 & .394 & 898.3 \\
\hline $\mathrm{Mg}$ limestone & 2460 & 11 & 5 & 34 & 1 & 37 & 1 & 9 & 2 & .471 & 1158.7 \\
\hline
\end{tabular}

In considering the crop index (which is the product of the yield figure and corresponding value of the grade index) it is still more evident that the two magnesian lime materials gave a far better return than the control and landplaster treatment.

From computed relative crop values (crop index of control = 100), the followingr resumé is obtained:

$\begin{array}{lll}\text { Control } & = & 100 \\ \text { Landlplaster + Emjeo } & = & 10.3 \\ \text { Hydratcd magnesian lime } & =111.5 \\ \text { Magnesian limestone } & = & 133.1\end{array}$

Once during the growing season (mid-fuly) and later, after the (rop) load been removed (October) samples of soil were collected from the four plots. Reaction and content of replaceable calcium and magnesiam (Morgan method) vere determined on these samples.

'The results aro fomel in 'Fable 9. With the exception of marrnesian linestone, no appreciable change in reaction was eflected 
through the use of various liming materials. Replaceable calcium increased during the season, apparently through nitrification or other biological processes in the soil.

If it be assumed that 50 pounds of magnesium per acre was the original content of the soil and that a small amount was incidentally supplied in the fertilizer, all the magnesium supplied as magnesium sulfate (Emjeo) and magnesium limestone was found to be replaceable, while hydrated lime was not so effective in this respect.

Table 9. Soll Reaction and Content of Replaceable Calcium and Magnesium in Soll of Lime Experiment Plots.

\begin{tabular}{|c|c|c|c|c|c|c|}
\hline \multirow[b]{2}{*}{ Treatment } & \multicolumn{2}{|c|}{$\mathrm{pH}$} & \multicolumn{2}{|c|}{ Calcium } & \multicolumn{2}{|c|}{ Magnesilim } \\
\hline & July & Oct. & July & Oct. & July & Oct. \\
\hline Control & 4.90 & 5.10 & 400 & 800 & 50 & 25 \\
\hline Landplaster+Emjeo & 4.84 & 5.10 & 750 & 1000 & 250 & 100 \\
\hline Hydrated lime & 5.04 & 5.10 & 750 & 1000 & 100 & 50 \\
\hline Magnesian limestone & 5.10 & 5.50 & 800 & 900 & 250 & 250 \\
\hline
\end{tabular}

\section{Leaf Content of Magnesium and Calcium}

Representative samples of lights (L) mediums (M) long seconds (LS) and long darks (LD) from the four treatments were gromnd up finely and analyzed ${ }^{1}$ for calcium and magnesium. The results are given in Table 10. In examining the data it is seen that, on the average, slightly more magnesium was deposited in the leaves when hydrated lime was the source than when the limestone was used.

It is of interest to note that calcium in hydrated lime was less readily taken up by tobacco than that from limestone. This, however, does not necessarily mean that the calcium in limestone is more readily available, but that the magnesia in this material may not have been so readily available as that in the hydrated lime. The reciprocal or antagonistic actions of the three main bases, - calcium, potassium and magnesium —- function to establish an acidbasic balance within the plant. That is, any one of the three bases makes up for the insufficiency of one or both of the others (See Bul. $444: 256)$.

Emjeo (magnesium sulfate) and landplaster in the present comparison were responsible for the highest leaf contents of both magnesium and calcium. This is in line with an earlier report (Bul. 386:584) that Emjeo furnishes more readily available magnesia than does magnesian lime. Calcium in landplaster (calcium sulfate), because of its chemical composition, as would be expected furnished more readily available calcium than either of the lime materials.

The results of this investigation suggest that either one of the two materials, magnesian limestone and hydrated lime, may be used

\footnotetext{
${ }^{1}$ By the Chemistry Department of the New Haven Station.
} 
as a source of magnesia with about equal adrantage, although the limestone might be safer to use in fertilizer mixtures of any combination.

It may be concluded that, while there may be a choice between the two lime materials when relatively small quantities of lime are required, if larger amounts must be applied (1,500 pounds up to one ton or more). calcic limes should be used in order to prevent a surplus content of magnesia in the leaf. The magnesia requirenent in the latter case is most readily filled in the fertilizer by inclusion of some magnesian lime or Emjeo.

Table 10. Content of Magnesium Oxide and Calcium Oxide in Tobacco From Air Dry Basis. Lime Plots. Crop of 1941.

\begin{tabular}{|c|c|c|c|c|c|}
\hline Liming materials & Grade & $\mathrm{CaO}$ & Av. & $\mathrm{MgO}$ & Av. \\
\hline Check & $\begin{array}{c}\text { LS } \\
\mathrm{L} \\
\mathrm{M} \\
\mathrm{LD}\end{array}$ & $\begin{array}{l}4.96 \\
4.16 \\
4.15 \\
3.68\end{array}$ & 4.24 & $\begin{array}{r}1.02 \\
.84 \\
.76 \\
.77\end{array}$ & .85 \\
\hline Hydrated magnesian lime & $\begin{array}{r}\mathrm{LS} \\
\mathrm{L} \\
\mathrm{M} \\
\mathrm{LD}\end{array}$ & $\begin{array}{l}5.11 \\
4.78 \\
4.48 \\
4.13\end{array}$ & 4.63 & $\begin{array}{l}1.94 \\
1.59 \\
1.56 \\
1.29\end{array}$ & 1.60 \\
\hline Landplaster-Emjeo & $\begin{array}{r}\mathrm{LS} \\
\mathrm{L} \\
\mathrm{M} \\
\mathrm{LD}\end{array}$ & $\begin{array}{l}6.00 \\
5.18 \\
4.77 \\
4.88\end{array}$ & 5.21 & $\begin{array}{l}1.97 \\
1.80 \\
1.58 \\
1.64\end{array}$ & 1.75 \\
\hline Magnesian limestone & $\begin{array}{r}\mathrm{LS} \\
\mathrm{L} \\
\mathrm{M} \\
\mathrm{LD}\end{array}$ & $\begin{array}{l}5.60 \\
5.06 \\
4.96 \\
4.66 \\
\end{array}$ & 5.07 & $\begin{array}{l}1.74 \\
1.40 \\
1.22 \\
1.12\end{array}$ & 1.37 \\
\hline
\end{tabular}

\section{RESIDUAL EFFECT ON STABLE MANURE}

In the Tobacen Substation Report for 1940 (Bul. 444:246) the results of the first year of an experiment to measure the residual or after-effect of a piecerling ten years of heary manure application were rescribed. During the first rear, although the nsual application of commereial fertilizer was used on all the field, those plots which had mamme lluring the previous years gave an increase of 2 ; pereent in yield and $3: 3$ percent in erading over the other parts of the field. 'jhis rexperiment is to be comtimed thromel a series of years in order to dotermine how long these eflects will last.

'The same four manure plots and corresponding controls were

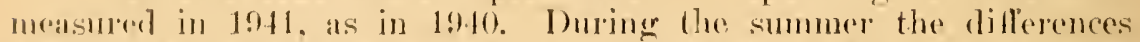
between the mamme plots and the other parts of the field were mot

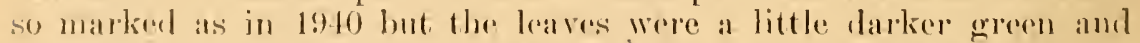

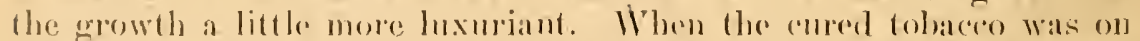
the sonting bench. no vory comsistont dillerences between them were observed with resperet to color, trextme, veins and other quality dhate- 
acteristics. The yields and grading of the plots are shown in 'Table 11. These data do not show any improvement in grading, but there was an increase of 136 pounds to the acre ( 7 percent) in yield. This is a smaller increase than was shown the first year but still shows that there was a distinct residual effect two years after any manure was applied.

Table 11. Yield and Grading Records of Resideal Manure Plots and Controls. CROP OF 1941.

\begin{tabular}{|c|c|c|c|c|c|c|c|c|c|c|c|c|c|}
\hline \multirow{2}{*}{$\begin{array}{l}\text { Previous } \\
\text { treatment }\end{array}$} & \multirow{2}{*}{ Plot no. } & \multicolumn{2}{|c|}{$\begin{array}{l}\text { Yield, Ibs. } \\
\text { per acre }\end{array}$} & \multicolumn{8}{|c|}{ Percentage of grades } & \multicolumn{2}{|c|}{ Grade index } \\
\hline & & Plot & Av. & L & $M$ & LS & 55 & $L D$ & DS & $F$ & $\mathrm{~B}$ & Plot & Av. \\
\hline \multirow{4}{*}{$\begin{array}{l}\text { Manure } \\
\text { two years } \\
\text { previous }\end{array}$} & $\overline{\mathrm{M} 1}$ & 1913 & & 5 & 4 & 27 & $\overline{1}$ & $\overline{39}$ & $\overline{6}$ & $\overline{11}$ & 7 & .386 & \\
\hline & M2 & 2100 & & 8 & 4 & 39 & 2 & 35 & 1 & 9 & 2 & .462 & \\
\hline & M3 & 2194 & 2086 & 1 & 2 & 36 & 2 & 38 & 2 & 12 & 7 & .381 & .410 \\
\hline & M4 & 2138 & & 3 & 2 & 38 & 1 & 39 & 2 & 9 & 6 & .409 & \\
\hline \multirow{4}{*}{$\begin{array}{l}\text { No previous } \\
\text { manure }\end{array}$} & $\overline{M c h 1}$ & 1819 & & 4 & $\overline{2}$ & 29 & 3 & $\overline{40}$ & 7 & $\overline{9}$ & 6 & .384 & \\
\hline & Mch2 & 1931 & & 8 & 3 & 35 & 3 & 36 & 3 & 10 & 2 & .443 & \\
\hline & Mch3 & 2063 & 1950 & 2 & 2 & 33 & 3 & 39 & 5 & 12 & 4 & .382 & .409 \\
\hline & Mch4 & 1988 & & 8 & 3 & 31 & 2 & 39 & 1 & 12 & 4 & .425 & \\
\hline
\end{tabular}

\section{FURTHER EXPERIMENTS ON STARTER SOLUTIONS}

From previous trials with starter solutions it was learned that by necessity they should be rather weak (Bul. 444:260-264). Recognizing this fact, in repeating the tests in 1941 the solutions used in the setter barrel were of a weak concentration.

The following solutions and concentrations were employed:

I. Nitrogen as nitrate of soda, 3 pounds per setter barrel (50 gallons of water)

II. Nitrogen and potash; 3 pounds nitrate of soda and 1 pound of sulfate of potash per setter barrel.

III. Nitrogen, phosphoric acid and potash, according to following formula :

50

32.5

13.5

4.0

$\overline{100.0}$ pounds superphosphate (16 percent $\mathrm{P}_{2} 0_{5}$ )

pounds nitrate of soda

pounds sulfate of potash

pounds Emjeo (magnesium sulfate)

Three and a half pounds of this mixture were used for 50 gallons of water, furnishing plant food at a ratio of 5-10-7.

On a field of rather low fertility, that had been previously fertilized at the rate of 2,500 pounds of $8-4-8$ per acre, rows of tobacco were planted, using plain water for check rows and, for alternating rows, the various solutions. Thus, there was one check row, followed by a row of solution I, a row of solution II and a row of solution III. This procedure was repeated so that triplicate test rows were obtained for check and treatments. The field was planted on June 4 and harvested on August 21. Yield and grading records 
are given in Table 12. From the data presented it is seen that starter solutions were decidedly beneficial. The results expressed in terms of relative crop values are:

$$
\begin{aligned}
& \text { Check }=100 \\
& \text { I. Nitrogen }=128.5 \\
& \text { II. Nitrogen and Potash }=128.0 \\
& \text { III. Nitrogen, phosphoric acid and potash }=127.1
\end{aligned}
$$

\begin{tabular}{|c|c|c|c|c|c|c|c|c|c|c|c|c|c|}
\hline \multirow{2}{*}{ Treatinent } & \multirow[t]{2}{*}{ Plot no? } & \multicolumn{2}{|c|}{$\begin{array}{l}\text { Yield, lbs. } \\
\text { par acre }\end{array}$} & \multicolumn{8}{|c|}{ Percentage of grades } & \multicolumn{2}{|c|}{ Crade index } \\
\hline & & Plot & Av. & $I$ & $\bar{M}$ & LS & SS & LD & DS & $F$ & $B$ & Plot & $A v$. \\
\hline \multirow{3}{*}{ Check } & A & 1790 & & & & & 13 & 40 & 7 & 20 & 20 & .213 & \\
\hline & B & 1759 & 1832 & & & 26 & 3 & 34 & 12 & 14 & 11 & .316 & .300 \\
\hline & $\mathrm{C}$ & 1947 & & & & 33 & 4 & 48 & 3 & 10 & 2 & .372 & \\
\hline \multirow{3}{*}{$\mathrm{N}$} & $\mathrm{I} \overline{\mathrm{A}}$ & 1862 & & 2 & 2 & 32 & 5 & 39 & 7 & 11 & 2 & .383 & \\
\hline & $\mathrm{J} B$ & 2063 & 2016 & 8 & 7 & 29 & 3 & 42 & 2 & 7 & 9 & .448 & .405 \\
\hline & $\mathrm{I} \mathrm{C}$ & 2123 & & & & 34 & 3 & 54 & 1 & 8 & & .385 & \\
\hline \multirow{3}{*}{$N \& \mathrm{~K}$} & $\overline{\text { II } \mathrm{A}}$ & 1792 & & & & 32 & 6 & 33 & 10 & 10 & 9 & .348 & \\
\hline & II $\mathrm{B}$ & 1892 & 1918 & 2 & 2 & 25 & 4 & 36 & 11 & 12 & ó & .344 & .367 \\
\hline & IJ $r$ & 2070 & & 5 & 2 & 31 & 4 & 44 & 2 & 11 & 1 & .408 & \\
\hline \multirow{3}{*}{$\mathrm{N}, \mathrm{P} \& \mathrm{~K}$} & III A & 1805 & & & & 28 & 6 & 31 & 12 & 11 & 12 & .326 & \\
\hline & III $\mathrm{B}$ & 1816 & 1883 & 5 & & 33 & 5 & 32 & $\theta$ & 9 & 7 & .393 & .371 \\
\hline & III CI & 2029 & & 4 & 1 & 29 & 6 & 46 & 5 & 9 & & .395 & \\
\hline
\end{tabular}

Table 12. Jield and Grading Records of Starter Solttion Tests. Crop of 1941.

The results indicate that nsing relatively weak starter solutions is beneficial, although it is strongly suggested that nitrate of soda alone will benefit both growth and quality more effectively than mixtures of several plant foods. In using nitrate of soda in the setter barrel it is suggrested that a stock solution be made up. such as 50 pounds to 50 gallons of water, of which not more than 3 gallons should be used for a setter barrel.

\section{USE OF CARBON BLACK TO ACTIVATE GROWTH EARLY IN THE SEASON}

It is commoniy known that black surfaces alsorth heat rays more efliciently than surfaces of other colors. witl a minimum of absorption when the surface is non-colored or white.

Similarly, a dark colored soil absorbs more heat than a light colored soil." If, therefore, a light colored soil conld be dirkened by some artificial nueans, it should absorb more of the sun's heat. 'This would probably benefit plants set ont early in the season when cold nights womld be a setback to erowth. A black material placed alrmul plants womld cause the soil to absorb and retain more heat (depending on molsture) and build up a reserve for the night.

In order to determine what eflect, if any, a blackened area aromel tobaren plants might have on growth and quality, a preliminary trial was made in the spring of 1941 . 
A quite uniform field was selected (field IV) and fertilized with a balanced mixture (2,500 pounds of 8-4-8 per acre). Seven rows of tobacco (150 feet long) were used for the experiment. 'To four of these carbon $\left(\right.$ Solium $^{1}$ ) was distributed in bands 4 inches wide on either side of the row. Alternate rows were left untreated as controls.

The carbon black was applied at the rate of 850 pounds per acre, although it is claimed that a 200-pound rate would be sufficient for other crops. The band on the surface of the soil was undisturbed for about ten days (carbon black applied on June 2 and cultivated the first time on June 12). In the early stages of growth it was observed that at least three of the four treated rows produced somewhat larger plants than the controls. It was thought that the material might have induced more favorable conditions for nitrification. Hence, concentration of soil nitrates was determined at three different times during the growing season. The results are listed below:

$\begin{array}{ccccc}\text { Treatment } & \begin{array}{c}\text { Pounds per acre of Nitrate } \\ \text { June } 10\end{array} & \begin{array}{c}\text { Nitrogen } \\ \text { June } 17\end{array} & \begin{array}{c}\text { Seasonal } \\ \text { average }\end{array} \\ \text { Control } 8 & \\ \text { Carbon black } \ldots \ldots \ldots \ldots \ldots & 53.6 & 95.8 & 51.0 & 67 \\ & 56.4 & 157.6 & 85.6 & 100\end{array}$

This material (Solium), claimed not to contain nitrogen as an impurity, apparently greatly accelerated the processes of nitrification - about 50 percent for the trial period.

The tobacco was harvested on August 18 and, after proper curing, it was sorted in the Station warehouse. As judged on the sorting bench, tobacco from the control rows was considered to be of very good quality, with occasionally a few starved (yellowish) leaves. The quality of tobacco from the carbon black treated rows was considered only fair. It was somewhat coarse, (as contrasted to the desirable smooth, silky texture) and a considerable number of starved leaves was found. The grading and yield data are found below.

\begin{tabular}{|c|c|c|c|c|c|c|c|c|c|c|c|}
\hline \multirow[b]{2}{*}{ Treatment } & \multirow{2}{*}{$\begin{array}{l}\text { Yield } \\
\text { per acre }\end{array}$} & \multicolumn{6}{|c|}{ Percentage of grades } & \multirow[b]{2}{*}{$\mathrm{F}$} & \multirow[b]{2}{*}{ B } & \multicolumn{2}{|c|}{ Index } \\
\hline & & L & M & LS & SS & LD & DS & & & grade & crop \\
\hline Control & 2172 & 9 & 4 & 31 & 2 & 37 & 1 & 10 & 6 & .435 & 944.8 \\
\hline Carbon bla & 2311 & 7 & 6 & 28 & 1 & 37 & 1 & 13 & 7 & .398 & 919.8 \\
\hline
\end{tabular}

It is shown that the carbon black treatment produced a somewhat higher yield than the control, althongh the increase is not big enough to cover the additional expense for material and labor. However, if the grading had been proportionally improved, that per se might have warranted its use. The grade index for the control was almost 10 percent higher than that of the carbon black. This gives the crop index (product of grade index and yield figure) for the control a value of about 945 as contrasted to that of the treatment, 920. These values, on a relative basis with 100 for the control, allow only 97.4 for the carbon black application.

\footnotetext{
1 "Solium" is a commercial grade of carbon black furnished by Binney \& Smith Company of New York.
} 
The result of one season's trial suggests no real adrantage in emploving a material. such as carbon black (Solium), for tobacco. To doubt, however, the material may be used to facilitate biological activities on soils where there is need for such a speeding up and for crops other than tobacco. With respect to tobacco in general and cigar leaf tobaceo in particular, quality is often more important than yield.

It is possible that, in the present test, most extensive production of nitrates occurred at a time when the plants were still too young to fully utilize the plant food. This is indicated by the exceptionally high level of nitrates on Jume 17 (157.6 pounds per acre); and, by the fact that the percentage of "darks" (LD and DS) was no higher for the carbon black tobacco than it was for the control, thus indicating that there was no oversupply of nitrogen when the crop was maturing. (A high percentage of "darks" is usually considered an indication of an oversupply of nitrogen in the soil.) It is also possible that a portion of the extra-early production of nitrates under the carbon black treatment may have been leached below the root zone by June rains.

\section{FURTHER INFORMATION ON IRRIGATION OF TOBACCO}

In previous reports ${ }^{1}$ it has been shown that irrigation of tobaceo during dry periods can be quite effective and profitable if measures are taken to prevent depletion of nitrate in the soil during the process. Further data along the same line were obtained by an experiment in 1941, although the season as a whole was not a good one for irrigation becanse the rainfall was suflicient and well distributed except for one period in mid-July.

On July 2:3 the tobaceo on one coarse sandy field was wilting badly and was therefore used for this test. One-third of the fiold was irrigated by rumning water down betweon the rows (method described in Bul. 391). Another third was not irrigated at all. The last. thirel was irrigated as montioned but, in ardelition, nituate of sola at the rate of 150 pounds to the acre was sprinkled into and dissolved in the water before it sank into the soil. The purpose of this was to replace any nitrate that would be leached away. The rate of watce application was oguivalent to abont ono and one-half inches of rainfall. It was phamed to repeat this a woek later hut timely lains made irrigation moneressitry.

When the aned crop was sorted, a high perentage of starved yollow leaves from the plots irrigated without nitrate indicated that

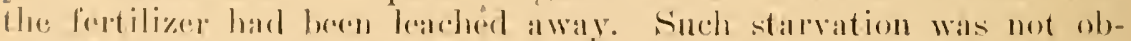
served on the irrigation plots to which nitrate of soda had heen addecl. 'The yicld and sorting records are slown in Table 13.

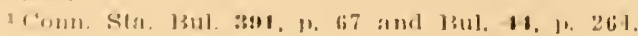


The data show that, on a sandy soil, irrigation alone may be more harmful than beneficial. It resulted in a reduction of 26 percent in the value of the crop (crop index). But when nitrate of soda was addect to the water there was an increase of 15 percent in the value of the crop. Both yield and grade index were materially increased. These differences are larger than we have had in tests of previous years but are all in the same direction. It is not likely that such large differences would be found if the soil was heavier and less prone to leaching. However, it is the lighter soils which the grower usually irrigates, because they are the ones that first suffer from drought.

Table 13. Yield and Grading Records of Irrigation Plots. Crop of 1941.

\begin{tabular}{|c|c|c|c|c|c|c|c|c|c|c|c|}
\hline \multirow{2}{*}{ Treatment 1} & \multirow{2}{*}{$\begin{array}{l}\text { Yield, } \\
\text { pounds } \\
\text { per acre }\end{array}$} & \multicolumn{8}{|c|}{ Percentage of grades } & \multirow{2}{*}{$\begin{array}{l}\text { Grade } \\
\text { index }\end{array}$} & \multirow{2}{*}{$\begin{array}{l}\text { Crop } \\
\text { index }\end{array}$} \\
\hline & & $L$ & $M$ & LS & SS & LD & DS & $F$ & $B$ & & \\
\hline Not irrigated & 1556 & 3 & 2 & 30 & 1 & 33 & 7 & 12 & 12 & .362 & 563.27 \\
\hline Irrigated alone & 1526 & - & - & 16 & 1 & 39 & 13 & 15 & 16 & .273 & 416.60 \\
\hline $\begin{array}{l}\text { Irrigated with } \\
\text { addition of } \\
\text { nitrate of soda }\end{array}$ & 1649 & 5 & 3 & 32 & 1 & 33 & 5 & 14 & 7 & .393 & 648.06 \\
\hline
\end{tabular}

1 Relative values based on crop index.

$\begin{array}{lr}\text { Not irrigated } & 115 \\ \text { Irrigated alone } & 74 \\ \text { Irrigated nitrate } & 100\end{array}$

The results of all experiments to date warn against the danger of this type of irrigation on "leachy" soils unless the nitrate content of the soil is kept up.

\section{LUMARITH AS A SUBSTITUTE FOR GLASS IN SEED BED SASH}

In our report for last year (Bul. 444, p. 269) the advantages of lumarith (a light, transparent, plastic, cellulose acetate) were described. 'The results of the first year's test were favorable and warranted a continuation of the trial. Sections of the seed bed were therefore covered in 1941 with the same limarith sash that wo had used in 1940. 'The sash had been kept over winter in a curing shed. By spring the plastic had become very brittle. Unless the sash was handled very carefully, the lumarith tended to split and break loose from the wooden frames. Before the seed bed season was over, most of the material had become unserviceable and had to be replaced with glass sash. Unless this fault can be overcome, lumarith can hardly be recommended because it is obviously impracticable to re-cover the frames each year.

There were no observable differences in growth of the plants in the seed beds covered by lumarith. They did not grow any faster than those under glass, nor was there any other difference in vigor, color of leaves, etc. 
It has been claimed by some experimenters that lumarith might have some effects that would be expressed in improved rigor in the field after transplanting. In order to test this, six rows of plants from the lumarith section of the bed were set in a field, each row alternating with a row of plants of the same age from the glasscorered parts of the bed. As far as could be observed there were no differences in growth betweeen the alternate rows in the field during the summer. Each was harrested, cured and sorted separately. The yield and sorting results are shown in Table 14 .

Table 14. Yield axd Grading Records of Tobacco From Lumarith and Glass Cotered Bens. Crop of 1941.

\begin{tabular}{|c|c|c|c|c|c|c|c|c|c|c|c|}
\hline \multirow{2}{*}{ Sash covering } & \multirow{2}{*}{$\begin{array}{l}\text { Yield, } \\
\text { pounds } \\
\text { per A. }\end{array}$} & \multicolumn{8}{|c|}{ Percentage of grades } & \multirow{2}{*}{$\begin{array}{l}\text { Grade } \\
\text { index }\end{array}$} & \multirow{2}{*}{$\begin{array}{l}\text { Crop } \\
\text { index }\end{array}$} \\
\hline & & $\mathrm{L}$ & $M$ & L.S & SS & LD & DS & $\mathrm{F}$ & $B$ & & \\
\hline Lumarith & 1853 & 3 & 2 & 40 & 2 & 39 & 2 & 10 & 2 & .421 & 780.09 \\
\hline Glass & 1913 & 1 & 1 & 35 & 2 & 39 & 2 & 11 & 9 & .398 & 761.37 \\
\hline
\end{tabular}

The yield was higher in the rows from the glass-covered beds but the grading a little better on the lumarith. The differences are probably too small to be significant or to indicate that any improvement in yield or quality was produced in the erop by growing the plants under lumarith.

\section{TOBACCO DISEASES IN 1941}

\section{P. J. Axperson}

Diseases of tobacco caused very little damage during 1941. Downy mildew was prevalent for a short time in the seed beds but cansed little trouble later and was almost absent from the fields. Not a single case was seen or reported of wildfire. blackfire, frenching. leaf blotch, sore shin or wet stalk rot. Of quite minor importance were damping-ofl, bed rot, black and brown root rot, hollow stalk and the various forms of pole rot.

\section{Some Experiments on Control of Downy Mildew}

The most common method of applying PDB is to place the erys1als in shallow wire baskets, abont 2 inches wile and 10 inches long. There are supported by nails driven into the side hoards of the beds. Althomgh the anly experinents showed that, nuder farorable temperature conditions, one hasket to aach two sashes is sufficient when one munce of arystals to cach four sumare yards of hed is msed, many of the growers are nsing one hasket. to each sash, "staggering" then on alternates sides of the berl. The degree of eontrol obtained has valred greatly from farm of farm dependting on (a) tightness of berds, (b) intervals between application, (c) time of starting treatuments, (d) length of treatment, etc. 
On the whole, however, it must be admitted that control of mildew by PDB, according to the method of application we have used, has not been entirely satisfactory, especially when the nights are cold. It is possible that a more thorough distribution of the gases in the bed might give better control.

In some tobacco sections of the country where cloth covers are used over tobacco beds, the crystals are distributed over the entire surface of a thin cloth which, in turn, is covered with a heavier cloth. This method gives a wider distribution of the crystals and, possibly, a more nearly equal gas concentration in the air than can be obtained by the basket method. This is reported to give satisfactory control. Since this method would not be very practical under our glass sash, a modification of the same principle was tried in our beds at the Experiment Station in comparison with the wire basket method.

Light frames $3 \times 51 / 2$ feet in size were covered with a thin cheese cloth. These frames were then supported under the glass above the plants by spike nails driven into the sides of the bed. The frames were spaced one to each 6 feet of bed. One ounce of PDB crystals was distributed evenly over each cloth frame every second night. In another section of the bed a similar amount was used in baskets, one to each sash, but staggered. A third section of bed was left untreated as check. Treatments were applied on May 14, 17, 19, 21, $23,26,28,30$ and on June 1, 3, 6, 9 and 11. The bed was inoculated thoroughly on May 15 and on June 2 by sprinkling all the bed with a suspension of spores in water.

On May 24 mildew began to appear on the check bed and continued to spread until there was 100 percent infection. On June 1 there was a little infection on the basket section. None appeared on the cloth section.

The cloth method thus gave better results than the basket method in this test, indicating that more thorough distribution of crystals may improve the degree of control.

Removal of PDB Crystals. The usual practice is to remove the PDB from the beds about $8 \mathrm{~A}$. M. daily. If the crystals are kept in the beds until it becomes too warm there is danger of plant injury from too great a concentration of the gas. This is indicated when the plants begin to fade to a yellowish cast. But, on cloudy days it does no harm to keep the crystals in the bed all day.

One progressive grower suggested that we should gauge the time of removal by the thermometer rather than the clock. To test his conviction he kept thermometers in the beds and removed the baskets only when the temperature came up to $80^{\circ} \mathrm{F}$. He did not have mildew in any of his beds during the setting period although he had mildew there regularly for several preceding years, and there was 
mildew in the beds of his neighbors. Unfortunately, he did not leave any untreated beds for a control this year.

Another arower found it too laborious to remove the baskets of crrstals each morning and. therefore. he left them in permanently but was careful to raise the sash and rentilate the bed during the day. He escaped mildew. The method is rather wasteful of material but sares labor.

Liquid Sprays. Although a considerable list of liquid sprays have been tried here for control of mildew, none of them has given satisfactory control. Most of them have caused leaf burning. or other types of injury, or have failed to control mildew. Nevertheless, new ones have been tried each year. One which we tried this year was the most satisfactory of any of the sprars we have yet found. This is a copper soap spray called "Flordo" which has been used with good results in Florida. ${ }^{1}$ In our tests this was prepared as follows: 1 pound of copper sulfate was dissolved in 15 gallons of water, and 4 pounds of soap (soap flakes) in 15 gallons of water. These two solutions were then stirred together. A small amount of curd that was formed was removed by straining through cheese cloth.

This was sprayed on the growing plants twice a week for four weeks. These plants and the unsprayed controls were inoculated twice with spores of mildew. The unsprayed checks finally became 100 percent infected. Nthough the section sprared with Flordo did not remain entirely free from disease, infection was light and did not cause scrions damage. Some of the leares were burned by the spray but not severely. Results indicate that this material should be subjected to further trial. A good spray might appeal to some of the growers more than the fumigation method now in general nae.

\section{Exit Wildfire}

This is the first season in 20 vears that the writer has failed to see or hear report of a single case of wildfire in the Commerticut $V_{\text {all }}$ ley. After its spectacular outhreak and destructive spread in the eally 'Twenties. wildfire began to be less prevalent each year. 'This gradual tapering off process eontinued until during the late Thirties it was musmal io find more than a dozen cases any rear. but each rear there ware alwals a few. Now it seems to have dropped out

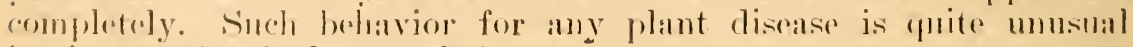
in the anmals of plant pathology.

\section{DELAYED FROST INJURY TO TRANSPLANTS IN JUNE}

I) ming the first two weeks of olune light frosts were reported from statterest localities after the plants weres started in the fiedsts.

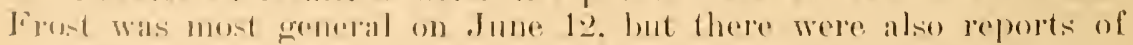

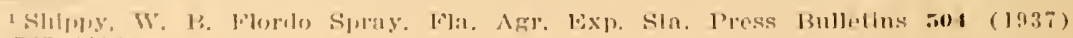
ant $517(1,10)$. 
quite localized frosts on other nights. The chill was not severe enough to cause the leaves to turn black and die. In fact, no one reported injury at that time. But within the next two weeks grower's began to bring in plants with peculiar markings which they were unable to diagnose. Having forgotten about the earlier frosts, they feared that another new disease had appeared here.

The most characteristic symptom of frost injury is the presence of broad white chlorotic bands, equally distributed on each side of the midrib and usually confined to the basal part of the leaf (See Figure 2.) The tips and upper parts of the leaves are commonly green and normal. The outer margin of the basal part may also be green, but frequently the chlorotic bands involve all the web of the basal part. The whitened, affected base fails to expand as the leaf

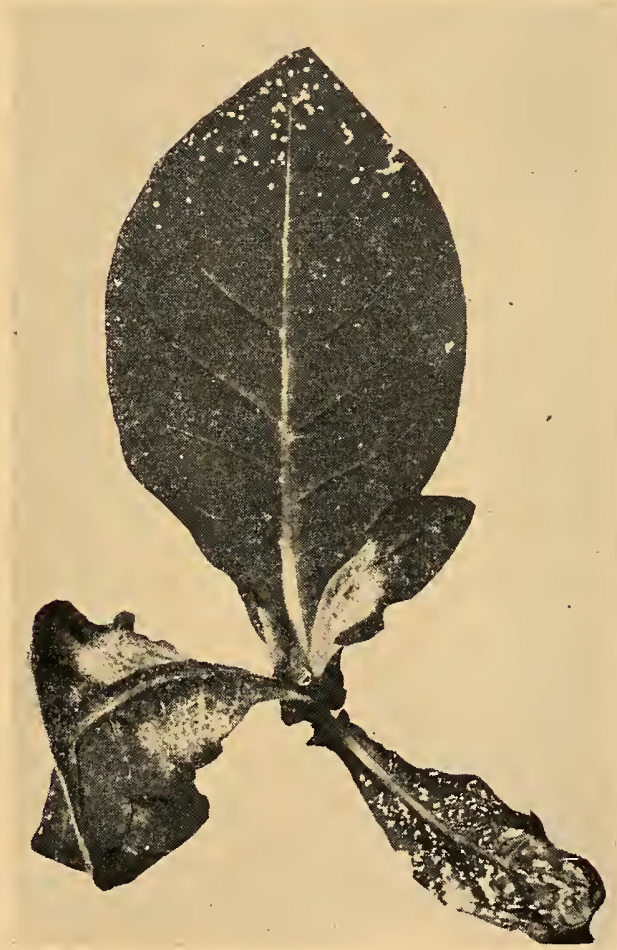

Figure 2. Delayed frost injury showing at center of young tobacco transplant.

grows and, therefore, appears narrow and pinched, making a sort of a handle to a spoon-shaped leaf. The margin of the injured part is usually wavey and the leaf variously distorted. The older, bottom leaves may be quite normal. Only the leaves that were quite young 
and tender at the date of the frost are involved. The affected area of the leaf may be solid white or may be rariously speckled and peppered with green.

In general the injury was found to be confined to limited parts of the field. All three types of tobacco were affected. Observations later in the year showed that all leares above the chlorotic lower ones dereloped normally; and the plant as a whole was not serionsly injured.

A similar condition occurred here in 1926 following a heavy frost on June 16 (See 'Tobacco Sta. Bul. 8 :5う for description and illustration). 


\section{MOSAIC OR CALICO DISEASE OF TOBACCO}

The season of 1941 was marked by unusual freedom from damaging diseases of the tobacco crop. But, contrary to this general statement, mosaic (known also among growers as calico, mongrel, brindle, gray top and rust) was more abundant than we have known it to be for many years. Its sudden prevalence aroused renewed interest among growers, and the Substation received numerous inquiries about its cause, spread and prevention. In view of this interest and the fact that we have been experimenting for several years on a method of control, about which information has not been previously published, this seems an opportune time to present an up-to-date picture of our present knowledge of tobacco mosaic.

It has been 12 years since we published a comprehensive article on mosaic (Tobacco Sta. Bul. 10, p. 75). In the interim the problems of mosaic diseases of plants have been extensively investigated by scientists. Their findings have greatly advanced our understanding and changed our conceptions of the causes of these diseases. Numerous articles by plant pathologists, physiologists and chemists have been published in journals and bulletins, but they are not available to many of our readers or are too technical for the practical tobacco man. The purpose of this article is to present in non-technical language the latest pertinent facts about mosaic.

Symptoms. Every experienced tobacco grower recognizes an ordinary calico plant in his field. The mottled appearance of the leaves, with splotched areas of greenish yellow between other areas of normal green, is familiar to all (Figure 3, top). Symptoms show all graduations of intensity. Sometimes the differences in shade of color are barely noticeable; at the other extreme, the light chlorotic areas of the leaf may be bright yellow to almost white and therefore stand out very sharply in contrast. Also, the pattern or mosaic, formed by the irregular alternating chlorotic and normal parts, is so extremely varied as to defy description. In some types, however, the darker areas have a tendency to follow the veins (Figure 3, bottom).

Attempts have been made to distinguish and name several types of mosaic according to differences in leaf symptoms, such as pattern or color of the chlorotic areas. There are, however, so many intergraduations between field types that, except for the mosaic specialist, such a classification adds nothing to clarity of understanding. In severe cases young leaves may become distorted or "puffed" and are inclined to be abnormally narrow. Plants affected early become dwarfed, do not make a normal growth and are practically worthless when mature. Late infestations with only a few of the top leaves shoring the symptoms, frequently not severe, are commonly known as "gray top" by growers. 

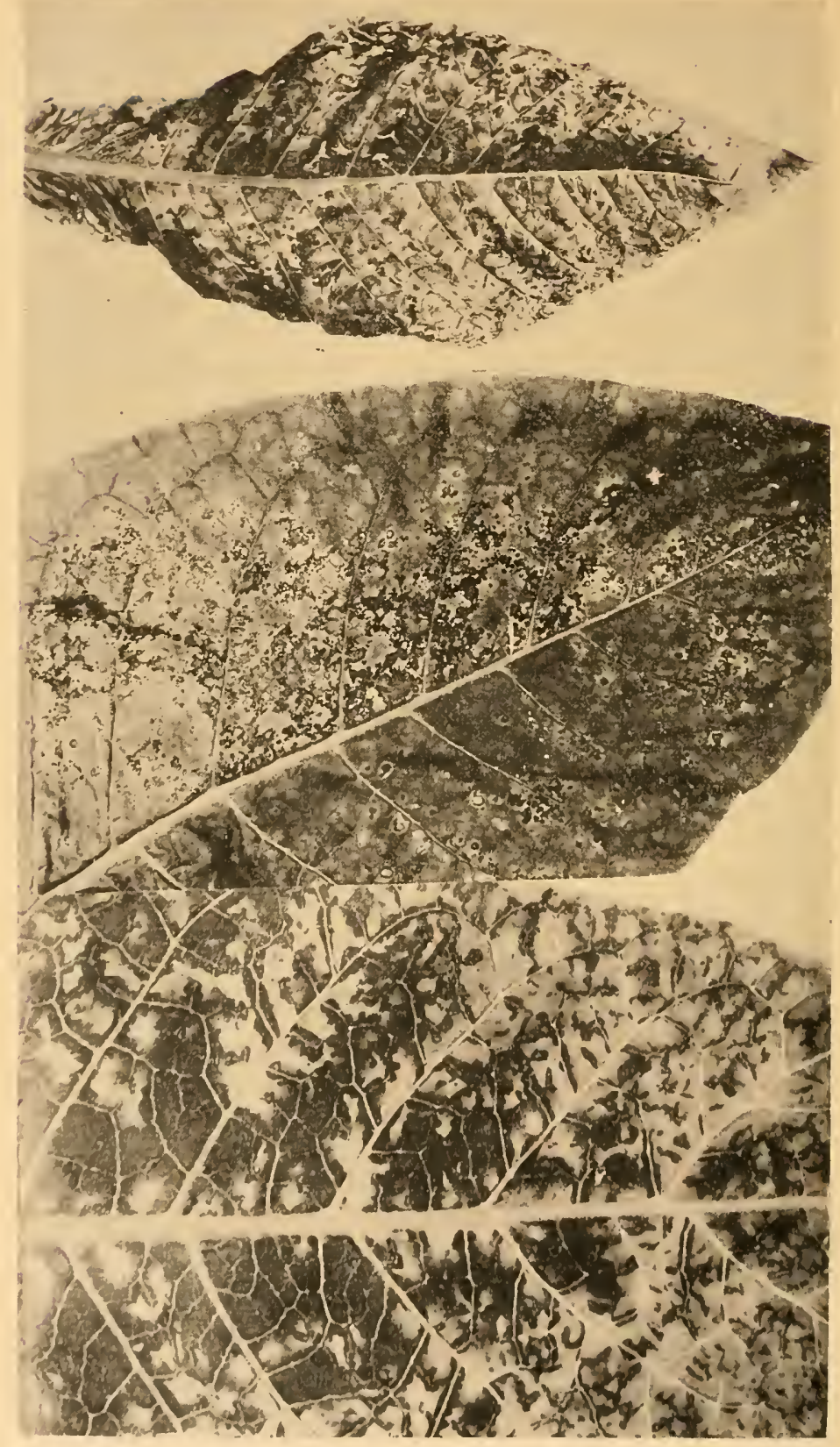

Figure 3. Tolateco laves sinowing patterns of mosalic: Top, the most crommen pattern of mottling; center, red rust, a sympon of calico marked loy irregulatr, dearl, brown patches; bottom, the pattern in which the dark areas follow the reins. 
But there are other symptoms which growers do not always realize are manifestations of the same disease. This is particularly true of the necrotic or dead spots of various shapes and colors that develop in the leaf tissue. These are of two general types and have been called white rust and red rust. The white rust, also called fleck, is marked by numerous small white spots peppered over the leaf. In the red rust type the spots are larger, more irregular and of a reddish brown color (Figure 3, center). 'This may be so severe as to canse death of the whole leaf. 'The red rust type, if more diffused, is sometimes called mosaic burn and appears often on the upper leaves of the plant. Burning of the top leaves usually results from the spread of mosaic while topping. Since such leaves often show no mosaic mottling, the grower is not aware of the connection.

Extent of Damage. Although mosaic recurs here every year, it is rarely a disease of major importance. In this section as a whole only a fraction of one percent of all the plants set contract the disease at a sufficiently early stage to suffer serious deterioration in quality or yield. An occasional field is found where the loss is heavy, and it is the occurrence of such cases that gives importance to the disease and the need of control measures.

The extent of damage to a plant depends largely on the stage of the plant's development at the time it becomes infected with the disease. A plant infected in the seed bed probably never attains sufficiently normal growth for its leaves to be suitable for cigar wrappers or binders. They might possibly serve as cheap scrap chewing tobacco. On the other hand, if infection occurs at the time of topping, the damage may be practically negligible, though, even at this late stage, considerable "burn" of the top leaves may result.

There are three sources of loss. (A) Dwarfing of the plants reduces yield. (B) The dead spots (white and red rust) reduce the value of the leaves somewhat in proportion to prominence of the spots. (C) A mottled leaf, when cured, has uneven colors, dead finish and is not elastic.

In a three-year experiment in Maryland, McMurtrey ${ }^{1}$ found that early infestations caused a loss of 55 percent of the gross value of the crop. In another three-year test in Kentucky, Johnson and Valleau" found that early infection reduced the yield 31 percent and the total value 40 percent. Even when infection occurred at topping time, the quality of the tobacco was reduced 25 percent. The losses in both of these tests are calculated on the basis of 100 percent infection - a condition that rarely occurs naturally - but they serve to

${ }^{1}$ MeMurtrey, J. E. Effect of mosaic disease on yield and quality of tobacco. Jour. Agr. Res. $38: 257-267$.

Johnson, E. M. and W. D. Valleau. Effect of tobacco mosaic on yield and quality of dark fire cured tobacco. Ky. Agx. Exp. Sta. Bul. 415. 1941. 
show that any degree of infection is damaging both to yield and quality.

The Causal Agent. Ever since tobacco mosaic was described 60 vears ago, a considerable variety of theories on its cause have been adranced and supporting evidence published to back each theory. Only in the last few years has the true cause been demonstrated and all the other alleged causes relegated to interesting past history. Mosaic is now known to be caused by a virus, appearing in the plant sap as minute rod-like particles of a protein nature which hare the remarkable characteristic of being able to multiply indefinitely in the living cells of all parts of the tobacco plant.

According to recent investigations ${ }^{1}$ an increase in these particles is at the expense of chromoprotein, which is in the protoplasm of all the cells of the plant. Whether or not the virus is composed of living organisms, it has definite parasitic properties. The cell cannot synthesize the virus de novo; a small particle of it must be introduced into a living cell in order to cause infection. Here it multiplies and spreads to other cells. When introduced into a tobacco plant, the virus spreads rapidly to the roots and to the newly dereloping leaves, but extremely slowly to leaves already fully grown. The symptous described above will appear on the leaves that were growing rapidly (rust) and on leaves which were very small (nottled) when infection occurred. All new growth will likewise be mottled. The particles of virus in the plant juice, which are designated as protein molecules by some investigators, are very minute, so small that they will pass through the pores of very finc filters. It would require about 125,000 of them placed end to end to span one inch.

Spread and Overwintering. Mosaic is extremely infectious and will spread from the most minute quantity of the virus transferred to the cell of a growing plant. From this point it quickly spreads in the sap to the roots and to the growing point of the plant. Once a plant is infected, it never recovers, since it has no way of eliminating the virus. When, in handling infected plants, the juice grets on the hands of the workman, he need only touch or rub his fingers over the leaf of a healthy plant to infect it. Any virus introduced into seed beds would be thoronghly disseminated by weeding or pulling the plants for setting. When there are a few infected plants established in the field, the virus may be spread around on hands, clothing, tools, etc. during any cultural operations. Fortunately, it is not spread by many of the common disseminating agents of fungous discases, such as wind and splashing rain. There is no conchlusive evidence that it is spread by insects.

Although the methods of dissemination in beds and field are well known, the means by which mosaic first grets its start each spring are

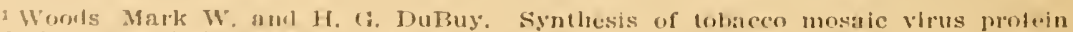
in relation to leif chromoprotelu and cell metabolism. Phytoritli. $31: 978-990.1941$. 
not so obvious. Its method of overwintering, however, gives some clue. In cured or dried leaves the virus will remain infective almost indefinitely. Thus Johnson and Valleau ${ }^{1}$ found it is still active in tobacco that had been kept in a case for 52 years. Its longevity is probably the most important fact to be kept in mind in connection with the prevention of mosaic. It will even survive in manufactured tobacco, such as cigars, cigarettes and chewing tobacco, although in smaller amounts than in the barn-cured tobacco.

Valleau has shown that in Kentucky the use of "natural" chewing tobacco by workmen tending the beds is the common source of initial bed infection. Badly infected beds have been observed in Connecticut where growers have used tobacco refuse, raked from the floor of curing sheds, as fertilizer. We visited a field in the summer of 1941 where one part of the field had 75 percent mosaic plants, while other parts of the field were relatively free of the disease. The infection was traced to the fact that the owner had ground up tobacco stalks from the previous year's crop and applied them as a fertilizer to the area of lowest fertility at time of setting the plants. This insured a thorough distribution of mosaic. In some sections of the country perennial weeds belonging to the tobacco family are sometimes infected, and the virus is transferred to tobacco plants while weeding. This does not appear to be a common source of infection here, however.

A great deal of investigation has centered on the ability of the virus to live in the soil over winter. It has been shown that in many soils the virus survives the winter, but probably only a very low percentage of infection may be traced to soil-borne virus from a preceding mosaic crop. The virus may be in the still undecomposed residues of the plants or may have been washed out into the soil itself. The percentage of virus that winters over in this way is obviously quite small. Otherwise, it would not be profitable to grow tobacco year after year in the same field. Every grower has seen fields where infection was about 100 percent on the suckers that grew up after a crop was harvested. Yet, a crop planted on that same field the next year would as likely as not be free from mosaic. If all the virus had remained active in the soil, there would be few healthy plants in the new crop.

No doubt, the greater percentage of virus becomes inactivated in the soil, especially in the upper layer which is stirred and well aerated before setting. Virus, like other protein substances, is decomposed by the action of soil organisms and thereafter cannot cause infection. The residues of tobacco plants quickly decompose when incorporated in the soil, especially if the soil is moist and well aerated. Investigators have shown that the type of the soil may have an influence on the ability of the virus to live over. This may explain the report

${ }^{1}$ Johnson, E. M. and W. D. Valleau. Mosaic from tobacco one to fifty-two years old. Ky. Agr. Exp. Sta. Bul. 361:264-271. 1935. 
by many growers that certain spots in their fields are prone to show mosaic more or less every year. The soil in these areas may be more suitable for keeping the virus in an active condition.

Control. No spray or dust is effective in controlling mosaic. Control measures must start with an understanding of the nature of the disease and. particularly, its method of dissemination as described above. Methods should aim, first, at preventing the introduction of the disease into the bed or field in the spring and, secondly. at removing infected plants which may spread it from plant to plant in the field.

The following preventive measures have been found useful and are offered as suggestions to growers whose crops are troubled with mosaic.

1. Tobacco refuse from curing sheds, sorting rooms or other sources should be kept entirely away from the seed beds. Sometimes tools or bed sashes, which have been stored in sheds without being carefully cleaned, may carry bits of diseased leaves to the beds.

2. If the stalks of a preceding crop are to be used on tobacco land for fertilizer, they should be plowed under the surface as thoroughly and early as possible to give them every opportunity to decay. If stalks are from a mosaic crop, or if results from this practice in previous year's have been bad, it is better to use them on land intended for other crops.

3. Men who are weeding, pulling or setting, or handling the crop in any way, should be discouraged from using tobacco. This applies to the use of the leaf in any form, but particularly in chewing and pipe tobacco.

4. Plants should never be set from a bed known to contain the disease. Mosaic plants are diflicult to detect in the seed bed. If only a few are fomd, it is quite certain that there are many other diseased ones which have not been "spotterl." Rather than risk spreacling the disease to the field it is better to sacrilice the whole bed. second and third pullines from a bert are much more likely to hate moxale than the first ones, becanse of spreal while pulling.

5. Inst alter the plants start in the field, "rogne" ont any diseaserl ones. Shout once a week, while the plants alre small, a workman shombl systemationlly inspect each row, pull up overy ralino plant and put it in a baket. 'This should be done before cultivating or performinge other operations which might spread the

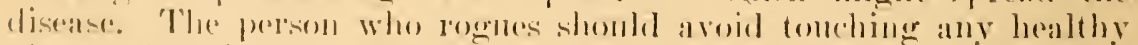
phat, otherwise he may spreat more disease than he removes. The

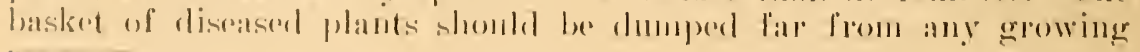

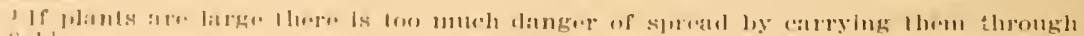
lhe. liolil. 
tobacco. The workman should thoroughly wash his hands before handling healthy plants again.

We regard this "rogueing" as a very essential measure of control. Both the Experiment Station farm and commercial growers have used it with success for many years. If it is carefully done, no other control measure should be necessary the remainder of the season. Rogueing is practicable only where the percentage of infected plants is small, but this is the condition in at least 95 percent of Connecticut fields. Where the percentage is very high, it is better to plow under the crop and replant from healthy beds.

6. If rogueing has not been successful, avoid spreading the virus from diseased to healthy plants during field operations, even at the time of topping and suckering. If there are several men working, one of them may handle all the diseased plants ahead of the others and not touch the healthy ones. This measure is of less importance than the preceding since the direct damage at this stage is not great, but it has some bearing on the practice mentioned in the next paragraph.

7. Every precaution should be taken to keep the entire tobacco farm free from mosaic. By carrying out sanitation practices the grower reduces chances of infection from refuse, which holds no danger if leaves and stalks are disease-free. Moreover, a soil which does not harbor mosiaic cannot spread infection. Some Connecticut tobacco farms have had practically no mosaic for years because the owners will not tolerate any sources of infection.

Mosaic Resistant Varieties. The perfect method of controlling any disease is to find or develop a strain or variety of the crop which is naturally immune or so highly resistant to the disease that need of further control measures is permanently eliminated. A resistant strain of tobacco must also have satisfactory commercial qualifications. The incorporation of good characters in a resistant strain may be the most difficult part of a breeding program.

Until 1933, it was currently believed that all varieties of tobacco were equally susceptible to mosaic and therefore offered little chance for the development of a resistant strain. Then Nolla and Roque ${ }^{1}$ found in Columbia, S. A., a variety of tobacco called Ambalema. This is so highly resistant to mosaic that common symptoms are absent, except for an occasional indistinct mottling of the lower leaves. Although Ambalema does not have qualities comparable to those of any types grown commercially in the United States, its factor of resistance may be bred into our present varieties by hybridization Several experiment stations and the United States Department of Agriculture are endeavoring to get suitable commercial resistant strains by using Ambalema as a parent. This hybridization pro-

${ }_{1}$ Nolla, J. A. B. and Roque, Arturo. A variety of tobacco resistant to ordinary tobacco mosaic. Jour. Dept. Agr. Puerto Rico 17:301-303. 1933. 
gram requires rears, selection and. although good progress has been made. we do not know of any investigator who is yet ready to distribute seed of a resistant rariety which he conisders to have suitable commercial qualities.

It this Station we are attempting to breed a resistant Broadleaf strain. Starting with a cross between Ambalema and John Williams Broadleaf, we have back crossed three times on Broadleaf. Many selections are satisfactorily resistant but they have not been tested long enough to make sure that they possess proper commercial qualities.

\section{INSECT INVESTIGATIONS DURING 1941}

\section{A. IT. Morrill, Jr., axd D. S. Iacroix ${ }^{1}$}

The cooperative investigations on the control of insect pests of tobacco in the Connecticut River Valley, which were commenced in 1936 by the Connecticut Experiment Station and the Bureau of Entomology and Plant Quarantine of the United States Department of Agriculture, were continued during 1941.

Various dust mixtures were tested on shade-grown and open field tobacco in an effort to obtain a simultaneous control of both potato flea beetle, Epitrix cucumeris (Harr.), and tobacco thrips, Frankiliniclla fusca (Hinds). Because of the impossibility of applying sprays cffectively to tobacco late in the season without causing mechanical injury to the plants, spray materials were not continued in the prowam. Naphthalene and carbon disulfide were tested as soil fumigants for the control of the eastern field wireworm, Limonius agoms (Siar). In addition, the field surveys and general observations of inscet ronditions on tobaceo were continued, as in previons years.

\section{Flea Beetle and Thrips Experiment}

Treatments were tested in an attempt to determine a single con[uol measure for use against both the potato flea bectle and tobacco thrips.

Although setting of tobacco plants was commended as early as May 15, this season. winds of 15 to 26 miles per hom blew almost enisantly, preventing dusting until . June 12. Thereafter, the treatments were applied at semi-weokly intervals when the weather permitfed motil July 11, when hrav showers prevented further dusting operations. Havesting of the jeaves was completed shortly therraftre. A total of eight applications was mate with each insecticide. the rate of application of dusts commenced at 6 jommds per ace at tho begrimning of the season and increased to 12 pounds per acre as the plants errew. Applications were madr by means of rotary

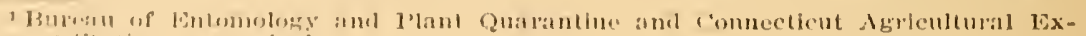

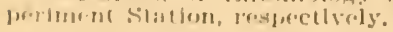


hand-operated dusters in the early morning, usually before $9 \mathrm{~A}$. M. Standard time, because this period of the day is freest from disturbing wind movements.

Each treatment, as in all similar tests conducted since 1937, was replicated six times on plots arranged in a Latin square. Each plot consisted of one bent of shade-grown tobacco, or one-fortieth acre. In conformity with the methods used in previous experiments, four primings of three leaves each were harvested from each of 10 plants, also chosen at random, in every plot. These leaves were then cured, fermented and processed in the usual commercial fashion. They were later examined for evidences of insect injury, which may be either more or less apparent on the cured leaf than on the green.

Three criteria were used in judging the effectiveness of the treatments, as follows: (A) the populations of flea beetles and thrips as sampled at intervals during the growing period of the crop, (B) the percentage of cured leaves showing evidence of feeding injury by these insects, and (C) the percentage of the total potential wrappers (four per leaf) showing injury severe enough to damage the value of the wrappers. Counts of live insects were made on (10) sample plants chosen at random in each plot immediately before and, again, 24 hours after each application of the insecticides. The percentage of leaves injured by feeding was determined by examining all leaves harvested from 10 plants per plot, as previously mentioned, after curing and processing were completed. In the case of the last-mentioned criterion, as applied to flea beetle feeding, injury severe enough to have caused commercial damage when properly located on the leaf was counted as actual damage when it was not so located. Thus this criterion is a measurement of the true severity of the injury, but overstates the commercial importance of such injury in the case of the flea beetle.

The use of pyrethrum dust gave better control of thrips in terms of wrappers damaged than did any of the other treatments, except that it was not significantly better than the treatment in which pyrethrum was alternated with cubé. There was no significant difference in the effectiveness of these two treatments and that of the dust mixture containing 1 percent of rotenone in controlling the flea beetles. All treatments were better than no treatment.

\section{Control Experiments on Open Field Tobacco}

A somewhat similar experiment on the control of tobacco thrips and the potato flea beetle was conducted on plots of open field tobacco in Buckland, Conn. Each treatment was replicated four times on plots one-fortieth acre in size that were arranged in two randomized blocks. The treatments used consisted of semi-weekly applications of the dusts shown in Table 1 during the period August 1 to August 16. These dusts were applied by means of rotary hand-operated dusters 
at rates of 3 to 30 pounds per acre, depending upon plant size. The effectiveness of treatments was determined by counts of living flea beetles and thrips on 10 plants per plot just before and $2+$ hours after each application. The results from this experiment are given in Table 1.). These data show a trend somewhat similar to that of the results on shade-grown tobacco.

The large decrease in thrips population after the fourth application was probably due to heavy thunder storms which came in clondburst proportions, not only washing off many of the thrips but also spattering the tobacco foliage with mud to such an extent that it was difficult to make accurate counts.

The figures accumulated in 1941 on Broadleaf tobacco bear out the same facts as were found in 1940 on Havana Seed tobacco, i. e., pyrethrum does serve to hold thrips in check to a certain degree, but is not entirely satisfactory.

Pyrethrum dust with a mineral diluent left a white residue on the tobacco leaves. This had a tendency to wash down towards the base of the leaves during rains and accumulated there. During dry weather, the white residue was plainly visible over all the foliage.

\section{Wireworm Control Experiments}

On June 6, twelve plots, one-fortieth acre in area (33 x 33 feet) were treated with naphthalene at the rate of 800 pounds per acre. applied in furrows 9 inches deep, approximately 9 inches apart, and later harrowed. Twelve others were plowed and harrowed, but were not treated with naphthalene. Twelve similar plots were treated with dichloroethyl ether, applied in the sctting water at the rate of $100 \mathrm{cc}$ of ether per gallon, about one-third to one-half pint of the mixture being applied around each plant. 'This ether was mate more soluble in the water by the addition of a commercial cat-ion-active emulsifying agent at the rate of :3 parts by volmue of the agent to 100 parts of: watcr. 'Twolve additional plots were troated with setting water. containime 2 grams of pala-Aminoacetamalide and 12 were plowed. harrowerl. and set with plain water. The 48 plots were alramed in 12 dandomized blocks. The effectiveness of the treatment was detelmincel by comting the wireworms obtained in sifting the soil from six mits of 1 culfic foot each, locater at random in the contral portion of earle plot. The plots were set with tobacco three days after tratmont with maphthalene, and no diflerence could be noted in the viger of the plants on the trated and untreated plots. Howrere.

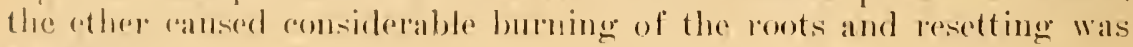
uccessistily.

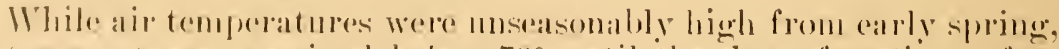

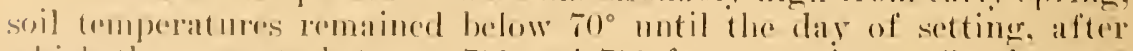
which they rese to betweren $70^{\circ}$ and $75^{\circ}$ for some days. On June 15

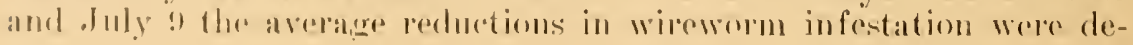


Tobacco Substation Report for 1941

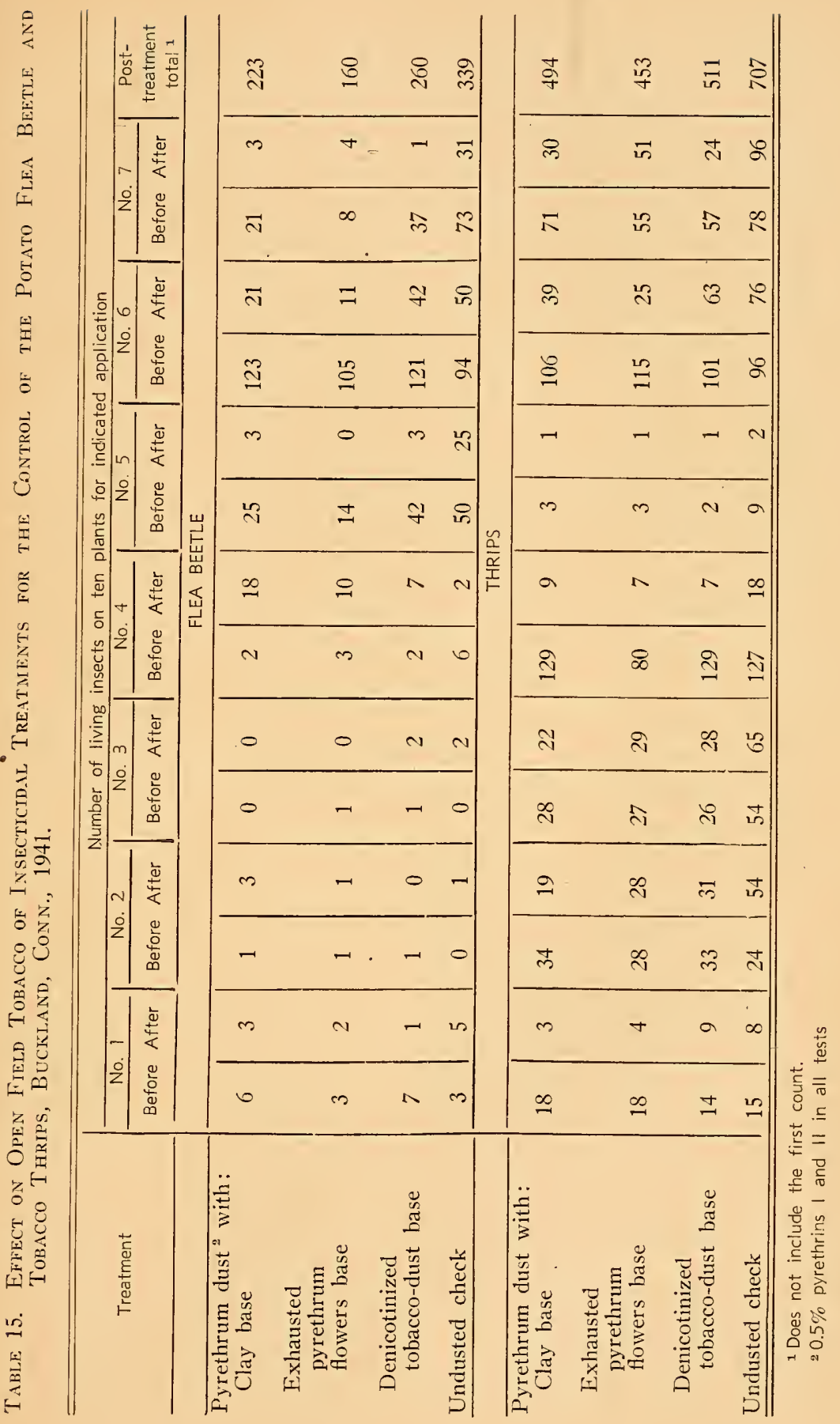


termined by soil sampling. The results of the samplings taken on .June 18 were not significant. Those of the sampling taken .July? are shown in Figure 4. While the reduction in wireworm infestation was barely significantly greater in the plots treated with naphthalene than in those not treated and somewhat more so in the plots treaterl with the ether, the reductions obtained were not sufficient to be of much practical value to the grower.

In September a new set of 36 plots was arranged in randomized blocks in a field which had been heavily infested at setting time and in which 6 resettings were required to get a stand. Twelve plots were treated with carbon disulfide immediately following the remoral of the tobacco plants after harvest. Twelve plots were plowed to a depth of about 1 foot and 12 were left untreated, except that all 36 were harrowed before and after the plowing. Temperatures remained fairly high during the period, the arerage daily departure being 2.T Fahrenheit degrees above normal. A reduction in the wireworn population of 87 percent was obtained in this experiment, which is considered to be highly significant (Figure 4 ).

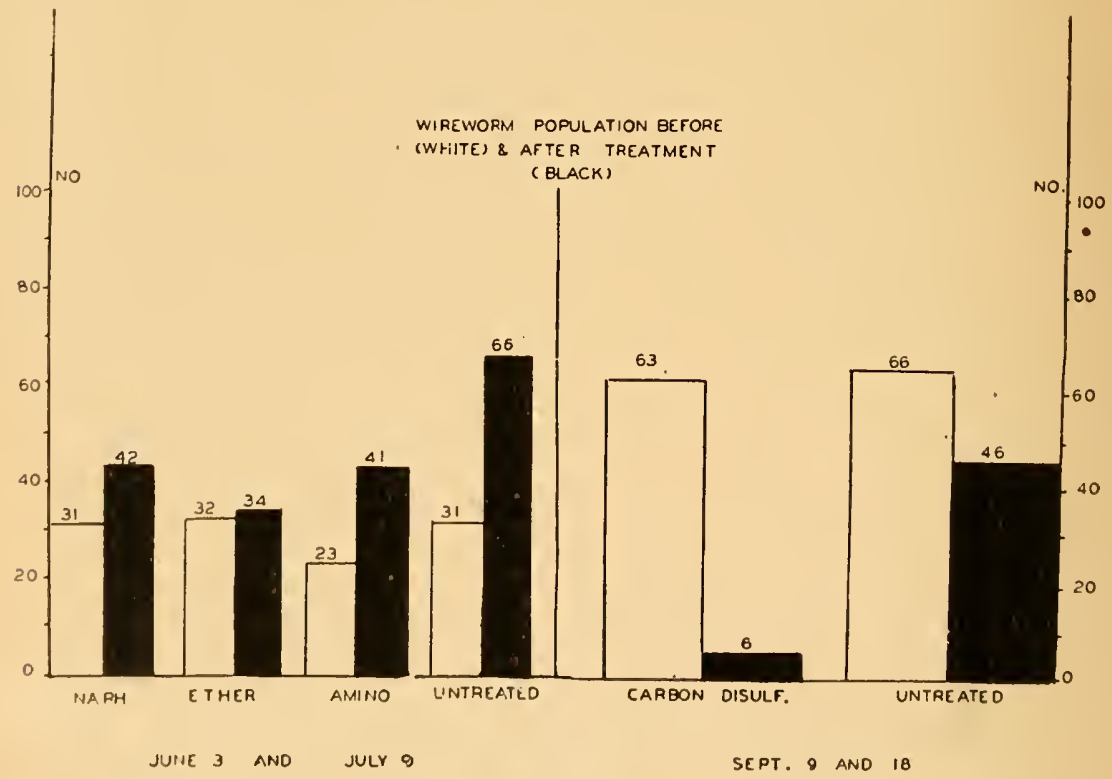

Figure 4. Results of treatments applied for the control of wireworms in inbacco fictels, Bucklanel, Comm., $19+1$.

\section{Insect Abundance During 1941}

1 sillerey to determine the sereovity of damage by inserets to open

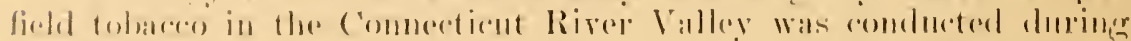

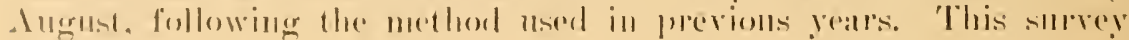


showed that the damage by insect pests was less severe than in 1940 and much less severe than for a number of years preceding. As in 1940, many pests were late in becoming established and some of the usual pests were not present in any appreciable numbers.

Percentages of leaves showing injury and of those showing commercial damage caused by the insects of major importance were as follows : Flea beetles, 20 percent and 7.97 percent, respectively; thrips. 6.54 percent and 1.84 percent; grasshoppers, 7.31 percent and 1.01 percent; and hornworms, 2.66 percent and 0.59 percent.

The Japanese beetle, Popillia japonica (Newm), again was observed feeding on tobacco, but not in such large numbers as in 1939 and 1940. As in previous instances, injury was confined to the tops of the plant and was very moderate.

The wireworm Limonius agonus (Say), which has been often reported under the name Limonius ectypus (Say), is frequently a severe pest of newly set tobacco in the Connecticut River Talley. In 1941 this insect was an especially serious problem, probably because of the unusual earliness of the setting of the young plants in the field. Many fields were attacked so heavily that restocking was necessary five and six times and, since the resetting must be done by hand rather than by the usual setting machinery, these operations were unduly expensive. Attack was usually confined to small areas in certain fields, as is normally the case but, in some instances, whole fields of fifteen to thirty acres were affected. This latter condition was seen especially in fields which have been set alternately to both potatoes and tobacco. Damage by the seed corn maggot, Hylemya cilicrura (Rond.), was not reported or observed, nor was there any damage by crane fly larvae or "leather-jackets," which in this region usually are the larvae of Nephrotoma fermginea (F.), sodalis (Loew), or Tipula georgiana (Alex.).

The potato flea beetle, Epitrix cucumeris (Harr.), and the tobacco thrips, Frankliniealla fusca (Hinds), were very scarce following heavy rains early in the season, but became almost normally abundant just before harvest. Injury by the flea beetle was approximately as general as last year, but leaf infestation was not as heavy. On the other hand injury by thrips was unexpectedly severe on cured leaves. Whereas excessive feeding by this insect will cause the leaf to become thin and papery and thus of little value, even moderate injury causes a white streaking of the leaf. When populations are small, this streaking is confined to the midrib section and is of little importance. However, during dry seasons, if no control measures are applied, the thrips may crowd farther out onto the leaf, and injury is caused to the wrapper portion of the leaf. This occurred during the latter part of the 1941 season.

Grasshopper's were rare until near harrest time, when more feeding than normally was observed in outside rows, probably ow- 
ing to the drought conditions. The injury in these fields was cansed mainly by the red-legged grasshopper. Metanoplus temur-pul,mm. (De G.) and, rarely, by the Carolina grasshopper, Dissosteira carolina (L.). Cutworms in seedbeds were not reported and few cases of injury by these insects to the growing plants were observed.

Other usual pests of tobaceo in this region, not reported in 1941, include the tarnished plant bug, Lygus pratensis oblineatus (Say), the garden springtail, Bourletiella hortensis (Fitch), and the stalk borer. Papaipema netris nitela (Guen). The spined stink bug. Euschistus variolarius (Beauv), the spotted cucumber beetle, Diabrotica duordecimpunctata (F). and the potato aphid, Macrosiphum (Illinoia) solanifolii (Ashm.), were found doing only very slight damage.

No specimens of the tobacco budworm, IIeliothis virsescens (F.). were observed. A few light infestations of the tobacco hornworm, Protoparce quinquemaculata (Haw.), were observed on sun-grown tobacco before harvest, and several were found on the later sucker's. Although unlikely, it is possible for these worms to orerwinter in this region and to emerge as moths during succeding years. Such infestations on suckers are, therefore, potential sources of damage to subsequent tobacco crops, and the sucker's should be carefully destroyed when they appear after harvest. At the same time. growers should take care not to destroy larvae found crawling in curing sheds when these larvae are covered with the small. white cocoons of the parasite, A panteles congregatus (Say). Contrary to the general conception, these cocoons are not hornworm "eggs" but a potential source of a hornworm control of considerable value and effectiveness in this region. 





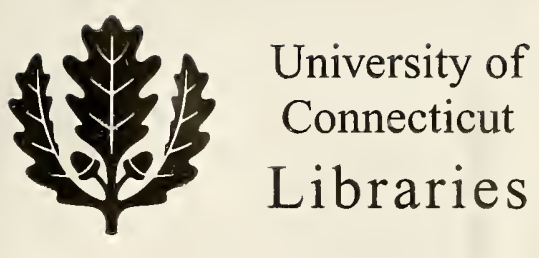

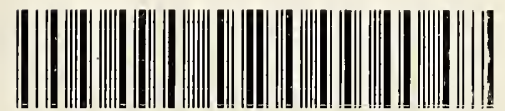
39153029345131 


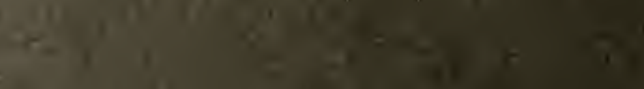

(4)

1

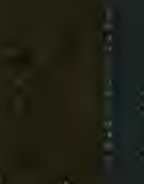

t.

$4=$

$$
-
$$

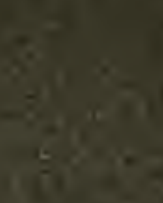

$x$

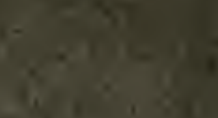

58

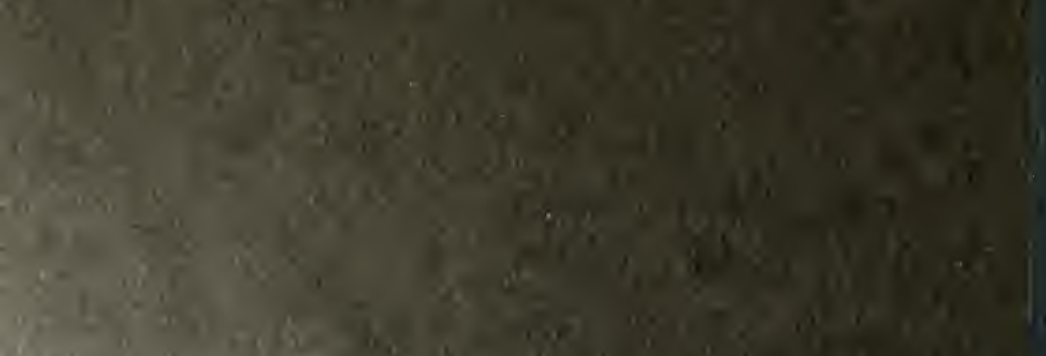
, 